Article

\title{
An Essential Role for Alzheimer's-Linked Amyloid Beta Oligomers in Neurodevelopment: Transient Expression of Multiple Proteoforms during Retina Histogenesis
}

\author{
Samuel C. Bartley ${ }^{1}$, Madison T. Proctor ${ }^{1}{ }^{\mathbb{D}}$, Hongjie Xia ${ }^{1}$, Evelyn Ho ${ }^{1}$, Dong S. Kang ${ }^{1}$, Kristen Schuster ${ }^{1}$, \\ Maíra A. Bicca ${ }^{1}$, Henrique S. Seckler ${ }^{2}$, Kirsten L. Viola ${ }^{1}{ }^{(D)}$, Steven M. Patrie ${ }^{2}$, Neil L. Kelleher ${ }^{3}$, \\ Fernando G. De Mello ${ }^{4}$ and William L. Klein ${ }^{1,5, * \mathbb{D}}$ \\ check for \\ updates \\ Citation: Bartley, S.C.; Proctor, M.T. \\ 1 Department of Neurobiology, Northwestern University, Evanston, IL 60208, USA; \\ samuelbartley2018@u.northwestern.edu (S.C.B.); madisonproctor2021@u.northwestern.edu (M.T.P.); \\ hongjiexia2019@u.northwestern.edu (H.X.); evelynho2019@u.northwestern.edu (E.H.); \\ a1g5m8@u.northwestern.edu (D.S.K.); kristenhschuster@gmail.com (K.S.); bicca.ma@jhmi.edu (M.A.B.); \\ k-viola@northwestern.edu (K.L.V.) \\ 2 Department of Chemistry, Northwestern University, Evanston, IL 60208, USA; hsseckler@gmail.com (H.S.S.); \\ steven.patrie@northwestern.edu (S.M.P.) \\ 3 Department of Molecular Biosciences, Northwestern University, Evanston, IL 60208, USA; \\ n-kelleher@northwestern.edu \\ 4 Instituto de Biofísica Carlos Chagas Filho (IBCCF), Federal University of Rio de Janeiro, \\ Rio de Janeiro 21941-902, Brazil; fgmello@biof.ufrj.br \\ 5 Mesulam Center for Cognitive Neurology and Alzheimer's Disease, Northwestern University, \\ Chicago, IL 60611, USA \\ * Correspondence: wklein@northwestern.edu; Tel.: +1-847-591-5510
} Xia, H.; Ho, E.; Kang, D.S.; Schuster, K.; Bicca, M.A.; Seckler, H.S.; Viola, K.L.; Patrie, S.M.; et al. An Essential Role for Alzheimer's-Linked Amyloid Beta Oligomers in Neurodevelopment: Transient Expression of Multiple Proteoforms during Retina Histogenesis. Int. J. Mol. Sci. 2022, 23, 2208. https:// doi.org/10.3390/ijms23042208

Academic Editor: Maria Laura Giuffrida

Received: 29 January 2022

Accepted: 14 February 2022

Published: 17 February 2022

Publisher's Note: MDPI stays neutral with regard to jurisdictional claims in published maps and institutional affiliations.

Copyright: (c) 2022 by the authors Licensee MDPI, Basel, Switzerland. This article is an open access article distributed under the terms and conditions of the Creative Commons Attribution (CC BY) license (https:// creativecommons.org/licenses/by/ $4.0 /)$

\begin{abstract}
Human amyloid beta peptide $(\mathrm{A} \beta)$ is a brain catabolite that at nanomolar concentrations can form neurotoxic oligomers (A $\beta \mathrm{Os}$ ), which are known to accumulate in Alzheimer's disease. Because a predisposition to form neurotoxins seems surprising, we have investigated whether circumstances might exist where $\mathrm{A} \beta \mathrm{O}$ accumulation may in fact be beneficial. Our investigation focused on the embryonic chick retina, which expresses the same $A \beta$ as humans. Using conformation-selective antibodies, immunoblots, mass spectrometry, and fluorescence microscopy, we discovered that $\mathrm{A} \beta \mathrm{Os}$ are indeed present in the developing retina, where multiple proteoforms are expressed in a highly regulated cell-specific manner. The expression of the $\mathrm{A} \beta \mathrm{O}$ proteoforms was selectively associated with transiently expressed phosphorylated Tau (pTau) proteoforms that, like A $\beta$ Os, are linked to Alzheimer's disease (AD). To test whether the $\mathrm{A} \beta \mathrm{Os}$ were functional in development, embryos were cultured ex ovo and then injected intravitreally with either a beta-site APP-cleaving enzyme 1 (BACE-1) inhibitor or an A $\beta$ O-selective antibody to prematurely lower the levels of $A \beta O$ s. The consequence was disrupted histogenesis resulting in dysplasia resembling that seen in various retina pathologies. We suggest the hypothesis that embryonic $\mathrm{A} \beta \mathrm{O}$ s are a new type of short-lived peptidergic hormone with a role in neural development. Such a role could help explain why a peptide that manifests deleterious gain-of-function activity when it oligomerizes in the aging brain has been evolutionarily conserved.
\end{abstract}

Keywords: neurodegeneration; neurodevelopment; avian embryo cultures; conformation-sensitive antibodies; tau

\section{Introduction}

Soluble oligomers of the $A \beta$ peptide $(A \beta O s)$ are neurotoxins that build up in brain and cerebrospinal fluid (CSF) of individuals with Alzheimer's disease (AD) [1-4]. They also manifest in transgenic AD animal models carrying the human amyloid precursor protein [5-10]. Experimentally, A $\beta$ Os induce memory dysfunction and multiple facets of 
$\mathrm{AD}$ neuropathology, and they are emerging as targets for $\mathrm{AD}$ therapeutics and diagnostics (for reviews, see [11-19]). Toxicity is a gain-of-function property that develops when oligomers are assembled from monomers [20]. Not all $A \beta$ monomers undergo stable oligomerization; however, the human $A \beta$ peptide comprising 42 amino acids $(A \beta 42)$ is unusually prone to do so. Although insoluble amyloid plaques were for many years considered the critical $\mathrm{AD}$ toxin, $\mathrm{A} \beta \mathrm{O}$ s have become widely regarded as the more diseaserelevant form of $\mathrm{A} \beta[21,22]$.

Given that human $A \beta 42$ readily generates oligomers that are potent central nervous system (CNS) neurotoxins, it is somewhat surprising that its sequence has been retained through evolution. One possible explanation is that under some circumstances $\mathrm{A} \beta \mathrm{O}$ s might serve a beneficial role. This idea is supported by a recent study showing that $A \beta O$ s can exert anti-viral action, helping protect the brain against herpes simplex virus [23]. A second possible role might lie in neural development, a possibility that is addressed here. Certain changes in the $\mathrm{AD}$ brain resemble those occurring in the developing brain, e.g., synapse elimination, selective nerve cell death, and gliosis [24-28]. These changes are pathological in the adult brain but are essential in the developing brain. Synapse loss and nerve cell death in $\mathrm{AD}$ models are triggered by $\mathrm{A} \beta \mathrm{O}$ s and involve hyperphosphorylated tau $[9,29-31]$; forms of $\mathrm{pTau}$ that mediate $\mathrm{A} \beta \mathrm{O}$-induced cell damage have been found to be expressed briefly in the developing brain [32-35]. If $A \beta O$ s were to be present during development, they would be expected to be transient, similar to AD-type pTau, as they are absent from healthy adults $[2,36]$.

The current study was carried out to investigate the hypothesis that $A \beta O$ s are transiently expressed in the developing nervous system and are required for proper histogenesis. Experiments were performed with the developing chick. Chicks are one of a number of species that retain the human $\mathrm{A} \beta 42$ sequence [37-40]), and developing chicks are known to transiently express a phospho-tau proteoform (pSer396/404) stimulated in various experimental models by $\mathrm{A} \beta \mathrm{Os}$ [29,41-43]. Experiments have focused on the retina, which is widely used as a model in studies of neural development [44-56]. The highly ordered laminar structure of the retina [57-61] is well-suited for the detection of developmental abnormalities, while the developing eyes of individual embryos are accessible to experimental manipulation.

The results show that $\mathrm{A} \beta \mathrm{O}$ s are present physiologically during the development of the embryonic retina. They manifest transiently, and their location and abundance is highly regulated. Experiments with embryo cultures show these $A \beta O$ s are essential for establishing proper cell placement during retina histogenesis. A requirement for transient $A \beta O s$ in neural development may be another reason why the human $A \beta 42$ sequence has been preserved in certain species, despite the great potential for neural damage caused by re-emergent $\mathrm{A} \beta \mathrm{O}$ s in the aging brain.

\section{Results}

\subsection{Alzheimer's-Linked ABOs and pTau Are Expressed in the Embryonic Retina}

CNS buildup of amyloid beta oligomers (A $\beta \mathrm{O}$ ) and hyperphosphorylated tau in the adult brain is associated with Alzheimer's pathogenesis [22,62]. Intriguingly, some proteoforms of pTau linked closely to AD also are expressed in the developing CNS, including pTau recognized by the AT8 antibody in the immature human brain [63] and pTau recognized by the PHF-1 antibody in the immature chick retina [32]. These forms of pTau are stimulated in various $\mathrm{AD}$ models by $\mathrm{A} \beta \mathrm{O}$ s $[9,29,31,41,42,62,64-68]$; however, the possible presence of $\mathrm{A} \beta \mathrm{Os}$ in the developing $\mathrm{CNS}$ has not been investigated.

We therefore asked whether the embryonic chick retina, which expresses PHF-1 tau, might also briefly express $A \beta O$ s. This possibility is in harmony with the fact that chicks express the same amino acid sequence of $A \beta 42$ as humans [38,69], which favors oligomer formation $[20,70,71]$. We first tested for the presence of $A \beta O$ s using a sensitive dot immunoblot assay. This assay was previously developed to detect $\mathrm{A} \beta \mathrm{O}$ s in extracts from $\mathrm{AD}$-affected human brains and AD animal models [2,5]. The antibody probe for the assay 
was the A $\beta \mathrm{O}$-selective mouse monoclonal NU2 [72]. Soluble extracts were obtained from embryonic retinas at ages when PHF-1 tau was present (embryonic days E7, E14, and E20). The dot blots showed an NU2 signal that became prominent by the second week of development but then decreased (Figure 1). The decrease was somewhat unexpected, as pTau detected by PHF-1 is expressed robustly until after the chicks hatch.

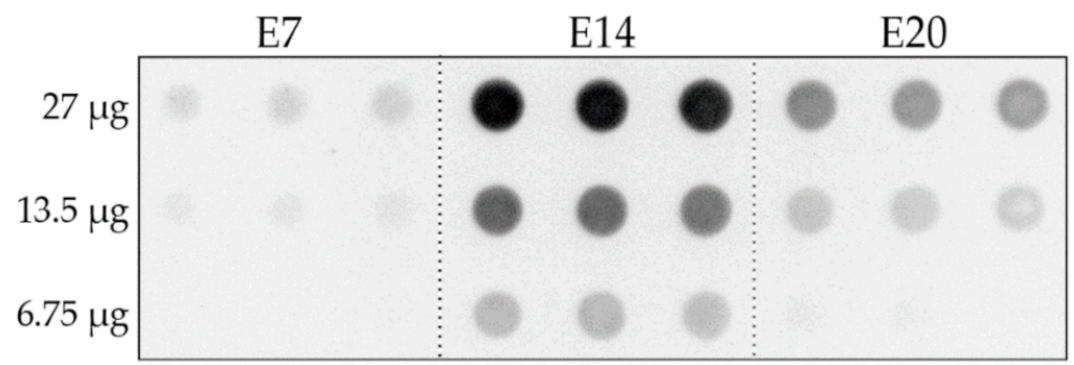

Figure 1. Dot immunoblots detect the presence of transient $\mathrm{A} \beta \mathrm{O}$ a in developing retina. Soluble extracts of retinas were obtained from embryonic chicks at ages E7, E14, and E20 and increasing doses were applied to the filter. A $\beta$ Os were detected using the mouse monoclonal antibody NU2. A major increase was seen between E7 and E14 followed by a prominent decrease between E14 and E20. $\mathrm{N}=3$ for each embryonic age.

We next tested whether another AD-associated pTau proteoform known to be stimulated by $\mathrm{A} \beta \mathrm{Os}$ [29] might also be present in the developing retina. This pTau proteoform is recognized by AT8, a monoclonal antibody that targets human tau phosphorylated at Ser202/Thr205 [73]; this proteoform is different from that recognized by PHF-1, which targets human tau phosphorylated at Ser396/404 [73]. Immunofluorescent imaging was carried out in AT8-labeled sections from retinas at embryonic days 8, 14, and 20 (E8, E14, and E20). As shown in Figure 2, the AT8 epitope was present in the retina, was cell-specific, and was sharply downregulated at the end of development. At E8, the AT8 pTau signal occurred in the ganglion cell layer (GCL) and part of the inner nuclear layer (INL). By E14, its distribution was the most prominent in amacrine cells (ACs), with clearly labeled, well-defined amacrine cells at the edge of the inner nuclear layer (INL). The distribution of AT8 extended into the sub lamina of the inner plexiform layer (IPL) associated with amacrine cells. At E20, the signal for the AT8 proteoform of pTau was virtually gone.
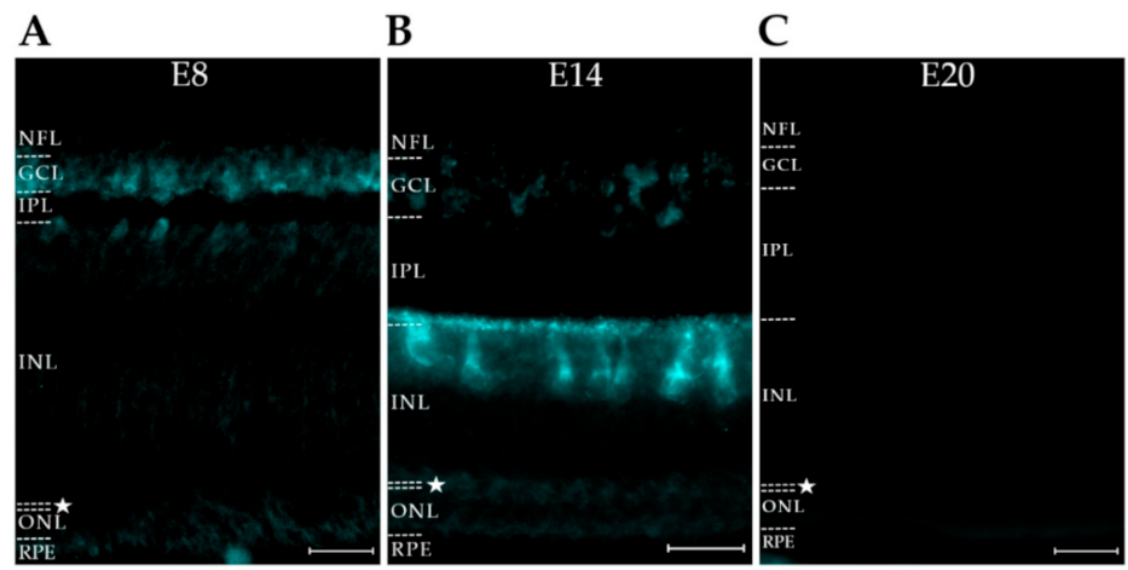

Figure 2. The Alzheimer's-linked AT8 pTau proteoform is briefly expressed in developing amacrine cells. Retinas from embryonic days E8, E14, and E20 were stained for pTau using AT8 (cyan). (A) E8: immunoreactivity is faintly present in the GCL and inner INL. (B) E14: immunoreactivity is present at the interface between the IPL and INL with highly specific staining of putative amacrine cells and their processes. Faint immunoreactivity is also present in the GCL. (C) E20: immunoreactivity is absent in all layers. The OPL is denoted with a star. Scale bar $=25 \mu \mathrm{m} . \mathrm{N}=2$. 
The spatiotemporal expression of the AT8 proteoform was markedly different from the pattern previously seen with PHF-1 [32]. At E20, when AT8 pTau was gone, the PHF-1 proteoform of pTau remained prominently expressed and was not downregulated until the chick was more mature (see Figure 1, ref [32]). An especially notable finding was that the PHF-1 and AT8 signals partitioned to different neuronal populations. PHF-1 is known to be prominent in ganglion cells, whereas AT8 was found to be prominent in amacrine cells. The disparate patterns of the two pTau proteoforms suggests the involvement of cell-specific mechanisms regulating their spatiotemporal expression.

\subsection{Verification of A $A O$ Identification Using Mass Spectrometry}

To substantiate the presence of $\mathrm{A} \beta \mathrm{O}$ s indicated by the dot immunoblots, we carried out a molecular level analysis of soluble chicken extracts from E16 retina using mass spectrometry. To begin, we determined that the $A \beta$ peptide from synthetic oligomers showed the expected molecular weight (MW) with a good P-score (not shown), allowing us to continue using this method for the analysis of chicken retina extracts. Proteins in the retina extracts were separated by gel-free electrophoresis (GELFrEE), fractions were assessed by SDS-PAGE, and silver staining was used to validate protein separation (Figure 3A). Putative $\mathrm{A} \beta \mathrm{O}$ s were found prominently in fraction 7 at a mass of approximately $45 \mathrm{kDa}$ when probed in a Western blot by the NU2 antibody (Figure 3B). Small amounts of signal were seen at a higher molecular weight in subsequent fractions. Western blots of unfractionated extracts from E14 retina using NU2 also showed the $45 \mathrm{kDa}$ band (Figure $4 \mathrm{~A}$ ). The proteins present in fraction 7 were analyzed by mass spectrometry (Figure 3D-G). We identified the $A \beta$ peptide in this fraction, as demonstrated by a total-ion-signal chromatogram (Figure 3D) and a background-subtracted extracted-ion chromatogram, for which only the signal within the expected $m / z$ of $[\mathrm{M}+5 \mathrm{H}] 5+\mathrm{A} \beta$ peptide isotopic peaks was accounted for (Figure $3 \mathrm{E}$ ). This was in harmony with the synthetic oligomer analysis. Interestingly, the A $\beta$ peptide proteoform eluted from the chicken retina fractions was found in its oxidized form, as depicted by matched peaks for $[\mathrm{M}+5 \mathrm{H}] 5+$ and $[\mathrm{M}+4 \mathrm{H}] 4+\mathrm{A} \beta$ peptide ions (Figure $3 \mathrm{~F}$ ) and by the fragmentation map (Figure 3G), in which fragment ions were matched within 10 ppm mass error to specific positions where backbone bonds were cleaved in the fragmentation process. The results confirmed by mass spectrometry that the GELFrEE fraction showing $\mathrm{A} \beta \mathrm{O}$ immunoreactivity at $45 \mathrm{kDa}$ contained the sequence of monomeric $\mathrm{A} \beta 42$ (4527 Da). This was confirmed in four independent experiments. The presence of $A \beta 42$ in the fraction comprising mid-sized proteins indicates that the $45 \mathrm{kDa}$ protein was an SDS-stable A $\beta$ 10-mer.

\subsection{Western Blots Show the Presence of Antibody-Specific A $\beta O$ Proteoforms}

In the GELFrEE fractions shown above, a prominent band at $\sim 45 \mathrm{kDa}$ was recognized by the $\mathrm{A} \beta \mathrm{O}$-selective mouse monoclonal NU2; however, additional minor bands were also seen, suggesting the possible presence of oligomers in the fractions with minor NU2-positive bands. To investigate further, Western blots using unfractionated extracts were carried out with two additional A $\beta \mathrm{O}$-selective antibodies. One was the humanized monoclonal ACU193, currently in a phase I clinical trial (ClinicalTrials.gov Identifier: NCT04931459), and the other was the well-studied mouse monoclonal NU4 [72,74]. As with NU2, these monoclonal antibodies were generated by immunization with full-sized $\mathrm{A} \beta \mathrm{Os}$ and cloned for $\mathrm{A} \beta \mathrm{O}$ selectivity. The Western blots of the retina extracts from each of three embryos showed prominent bands detected by all the A $\beta O$-selective antibodies (Figure 4), but these bands were detected differentially. Bands were found at $40 \mathrm{kDa}$ (NU2 and NU4), at $\sim 45 \mathrm{kDa}$ (NU2), at $\sim 72 \mathrm{kDa}$ (ACU193), and at $104 \mathrm{kDa}$ (NU4 and ACU193). The results indicate that the developing retina expresses at least four prominent sodium dodecyl sulfate (SDS)-stable A $\beta O$ proteoforms. How the different SDS-stable assemblies relate to each other in detergent-free extracts remains to be investigated. 


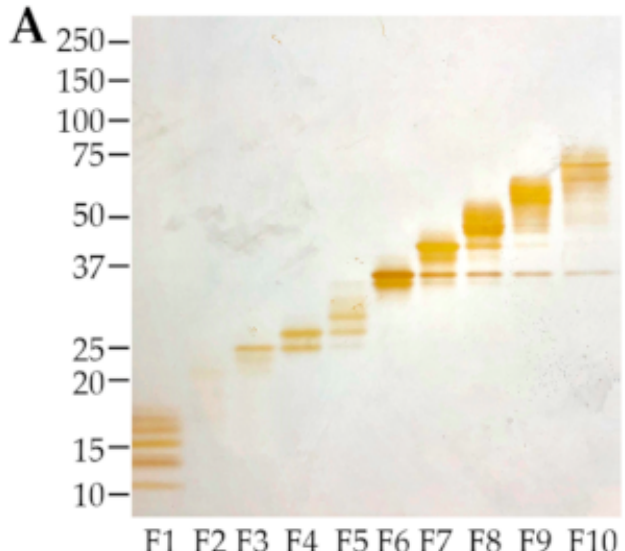

F1 F2 F3 F4 F5 F6 F7 F8 F9 F10
B

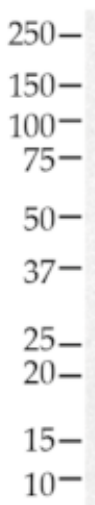

$\begin{array}{lllllllll}\text { F1 F2 } & \text { F3 } & \text { F4 } & \text { F5 } & \text { F6 } & \text { F7 } & \text { F8 } & \text { F9 } & \text { F10 }\end{array}$

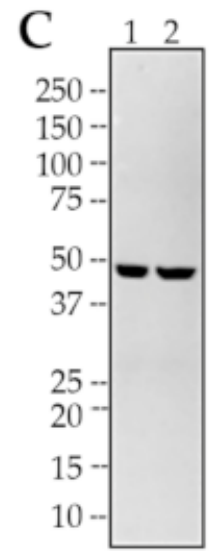

D

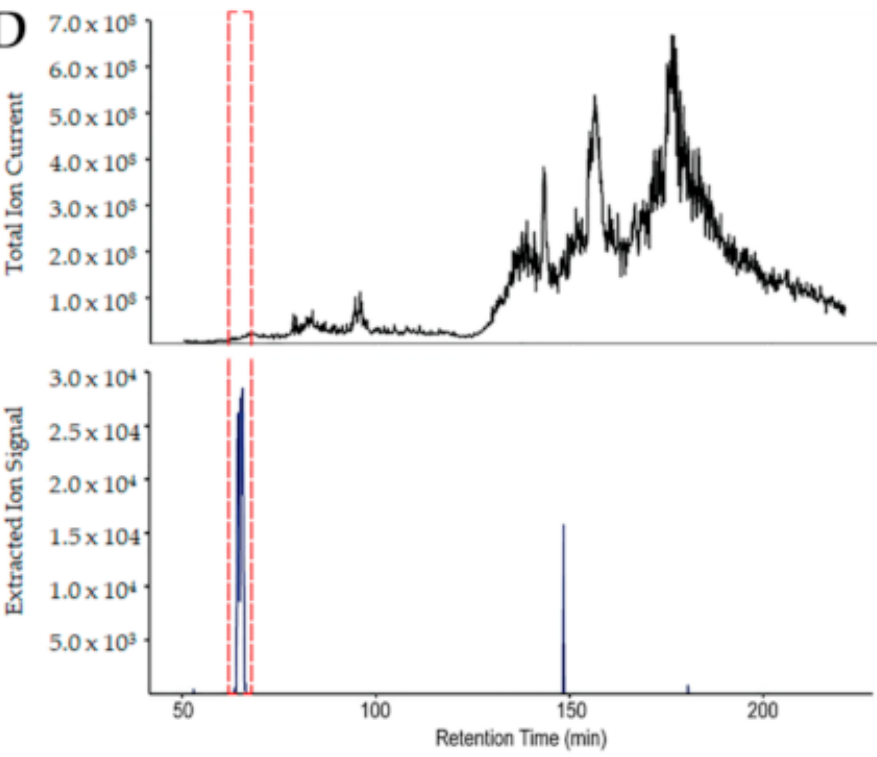

F

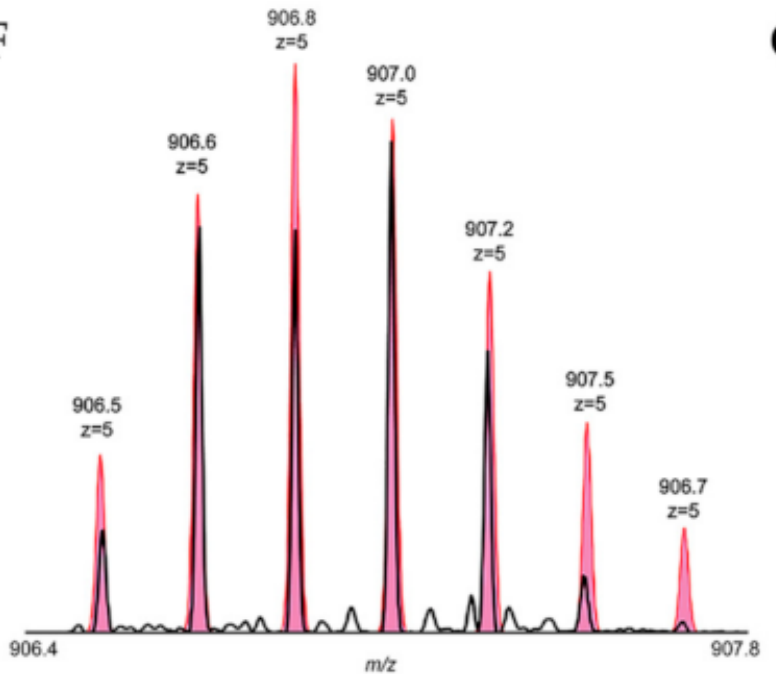

G
E

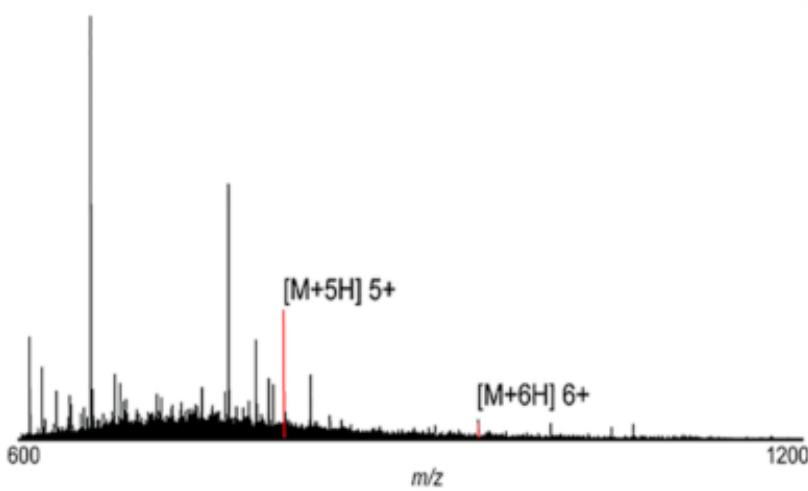

N D A E F R H Dls G Y E V HlH Q K L VlF F A $l_{21}$ 22 E|D V G|S N|K G AlI|I|G|L|M V G G V V I A C

Observed Mass: 4527.29 Da Theoretical Mass: 4527.26 Da Mass error: $5.65 \mathrm{ppm}$
P-Score: 1.1E-13

Residue Coverage: $29 \%$

Fragments Explained: $21 \%$

Figure 3. Endogenous $\mathrm{A} \beta \mathrm{O}$ expression in the embryonic retina is confirmed by mass spectrometry. (A) Soluble extracts of E16 retina were separated into 10 fractions by GELFrEE and each fraction was analyzed by SDS-PAGE and silver staining to establish protein separation. (B) Western blot of the GELFrEE fractions showed a prominent signal in fraction 7 at approximately $45 \mathrm{kDa}$ detected by the oligomer-selective NU2 antibody. (C) Western blots of unfractionated retina extracts (two separate extracts, 1 and 2, as labeled above each lane) also showed the $45 \mathrm{kDa}$ species. (D) Fraction 7 was 
analyzed by mass spectrometry, and the panel shows the total-ion-signal chromatogram (top) and a background-subtracted extracted-ion chromatogram (bottom). The panel indicates the only signal with the expected $m / z$ of $[\mathrm{M}+5 \mathrm{H}] 5+\mathrm{A} \beta$ peptide. The red dashed box indicates the retention time window in which the oxidized $A \beta$ proteoform was eluted. (E) The full intact mass spectrum is shown at the retention time for $\mathrm{A} \beta$ elution. Matched peaks for $[\mathrm{M}+5 \mathrm{H}] 5+$ and $[\mathrm{M}+4 \mathrm{H}] 4+\mathrm{A} \beta$ are in red. (F) The select-ion scan (narrow-window) of the $[\mathrm{M}+5 \mathrm{H}] 5+\mathrm{A} \beta$ peptide ion (black) is overlaid on its expected isotopic distribution (pink). (G) The fragmentation map is shown for the endogenous $\mathrm{A} \beta$. Fragment ions (blue flags) were matched within $10 \mathrm{ppm}$ mass error to give a specific position where backbone bonds were cleaved. Error in intact mass measurement, the percent of expected fragments observed (coverage) and of fragment peaks matched (explained), and a P-score calculated for confidence in protein identification are indicated. Data confirm that embryonic retina contains an SDS-stable A $\beta$ 10-mer, a result observed in at least four separate experiments.
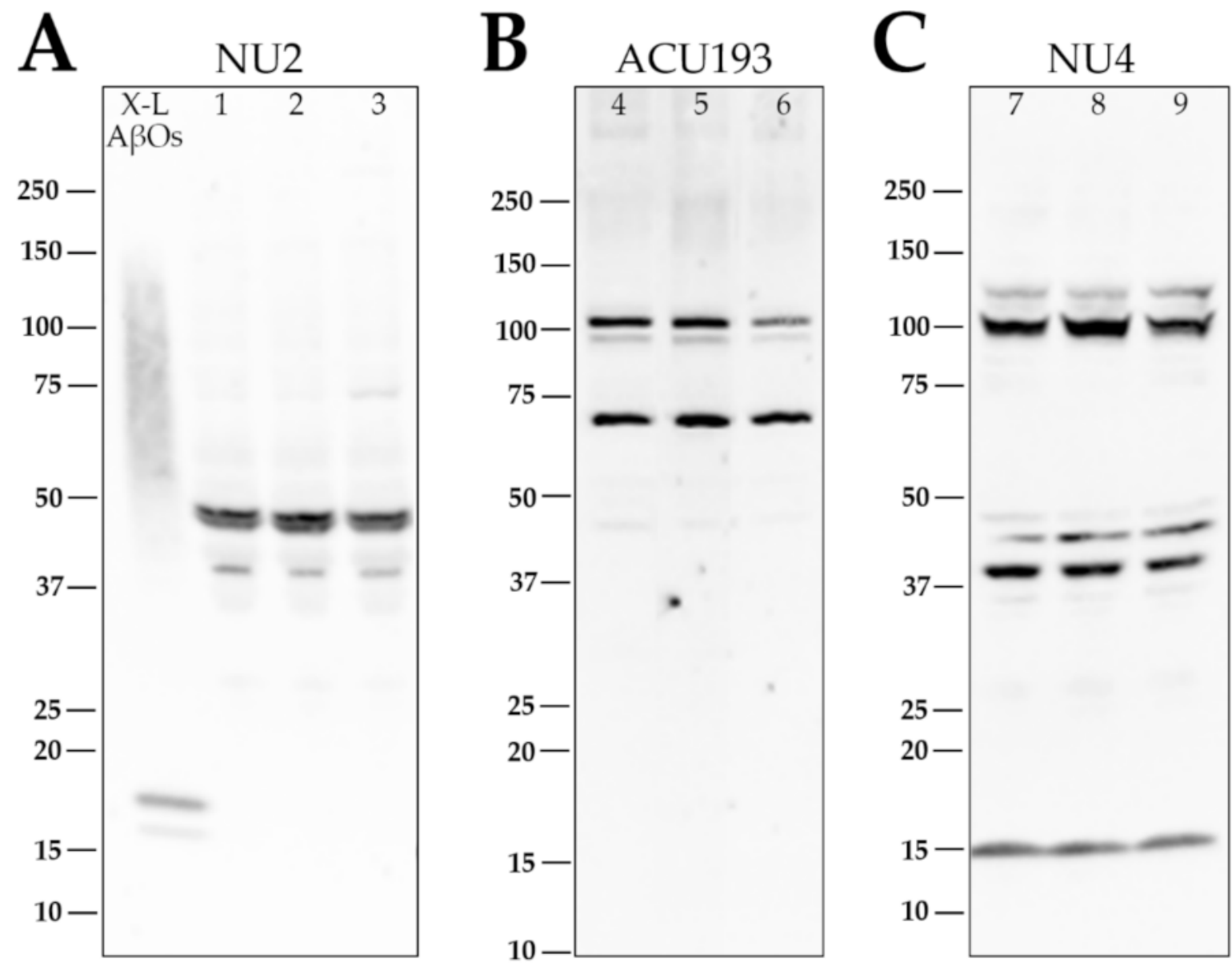

Figure 4. Retina $\mathrm{A} \beta \mathrm{O}$ s comprise proteoforms differentially recognized on Western blots by monoclonal antibodies NU2, ACU193, and NU4. Soluble extracts from three embryonic retinas were obtained at E14 and separated using SDS-PAGE (Tris-glycine gel) followed by transfer to a nitrocellulose membrane. This was repeated twice for a total of nine different retinas (1-9) on three separate membranes. A $\beta$ Os were identified using NU2 (A; 1-3), ACU193 (B; 4-6), or NU4 (C; 7-9). A $\beta$ Os identified with NU2 were most prominent as a doublet at $\sim 45 \mathrm{kDa}$ with a minor band just above $37 \mathrm{kDa}$. A $\beta$ Os identified with ACU193 had prominent bands at $\sim 72 \mathrm{kDa}$ and a doublet at $\sim 100 \mathrm{kDa}$. A $\beta$ Os identified with NU4 had prominent bands just above $\sim 37 \mathrm{kDa}$ and $\sim 100 \mathrm{kDa}$, with fainter bands at $\sim 14 \mathrm{kDa}, 45 \mathrm{kDa}$, and $125 \mathrm{kDa}$. The ability of NU2, ACU193, and NU4 to distinguish these distinct SDS-stable $\mathrm{A} \beta \mathrm{O}$ proteoforms was observed in three separate experiments. 


\subsection{ABOs Are Expressed in a Cell-Specific Manner}

The above results confirm that the E14 retina expresses $\mathrm{A} \beta \mathrm{O}$ s that are detectable by $\mathrm{A} \beta \mathrm{O}$-selective monoclonal antibodies (Figures 1 and 3 ). We next investigated the spatial distribution of the $\mathrm{A} \beta \mathrm{O}$ s to determine if their expression in the retina was homogeneous or associated with specific cell types. Immunofluorescence microscopy of NU2-labeled sections revealed a highly differentiated pattern of expression (Figure 5A). A $\beta$ Os in E14 retina showed a prominent presence in the inner nuclear layer (INL), at the inner edge where amacrine cells localize. An example that confirms $\mathrm{A} \beta \mathrm{O}$ s in amacrine cells is shown by the colocalization of $\mathrm{A} \beta \mathrm{O}$ s with choline acetyltransferase (ChAT), observed in doublelabeled retinas (Figure 5A-C). The overlay shows that virtually all ChAT-positive amacrine were co-stained with NU2 (Pearson correlation coefficient of $r=0.746$; [75]). This robust colocalization was seen in the soma and neurites of ChAT-positive amacrine cells. The diffuse labeling in the ganglion cell layer (GCL) may be associated with displaced amacrine cells, as the commercial ChAT antibody used here labeled these cells poorly (Figure 5B). On the other hand, not all $\mathrm{A} \beta \mathrm{O}$ in the amacrine cell region were found within cholinergic neurons, and in the IPL, a sub lamina of $A \beta O$ s not associated with ChAT could be seen that ran parallel to the $\mathrm{A} \beta \mathrm{O}$ s colocalizing with ChAT. The identity of other cell types that express $\mathrm{A} \beta \mathrm{O}$ s requires further investigation. The central point here, however, is that $\mathrm{A} \beta \mathrm{O}$ expression in the embryonic retina is highly differentiated at the cellular level, a conclusion substantiated by further double-labeling experiments with anti-ChAT and ACU193 (Figure 6). These experiments used a different ChAT antibody (a rabbit polyclonal anti-ChAT serum synthesized by Dr. Michael Mäder and gifted by Dr. Miles Epstein), which in this case robustly labeled the displaced cholinergic amacrine cells in the GCL. As before, virtually all cholinergic amacrine cells expressed $A \beta O$ s, this time detected with ACU193; however, not all A $\beta O$-positive cells were cholinergic. The two double-labeling experiments show that an identifiable neuron population contains $\mathrm{A} \beta \mathrm{O}$ s recognizable by two different mAbs, even though they do not detect the same bands on Western blots. Besides helping to substantiate the validity of $\mathrm{A} \beta \mathrm{O}$ expression in the developing retina, this result is intriguing in showing that the same neurons appear to express different $\mathrm{A} \beta \mathrm{O}$ proteoforms.
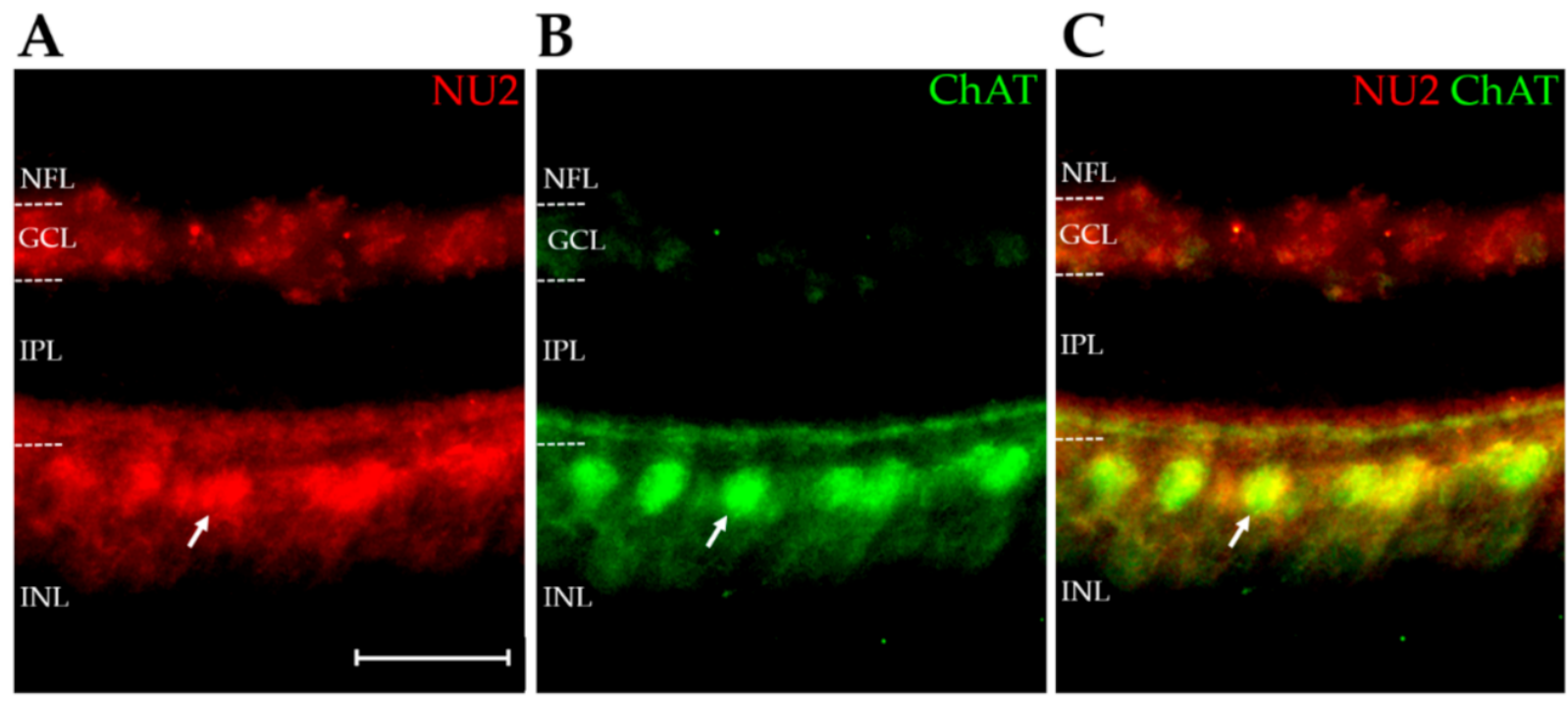

Figure 5. Embryonic cholinergic amacrine cells manifest NU2-targeted A $\beta$ Os. Retinas from embryonic day E14 were double-labelled for A $\beta$ Os using NU2 (red) and for ChAT using a commercially available antibody (green). (A) A $\beta O$ immunoreactivity is present in the GCL, outer IPL, and inner INL. (B) ChAT immunoreactivity is highly specific to the inner INL and cellular processes projecting into the outer IPL. (C) Overlay of NU2 and ChAT staining. Gold represents areas of colocalization. Arrow identifies a cell that is stained by both NU2 and ChAT. Scale bar is $25 \mu \mathrm{m} . \mathrm{N}=2$. 


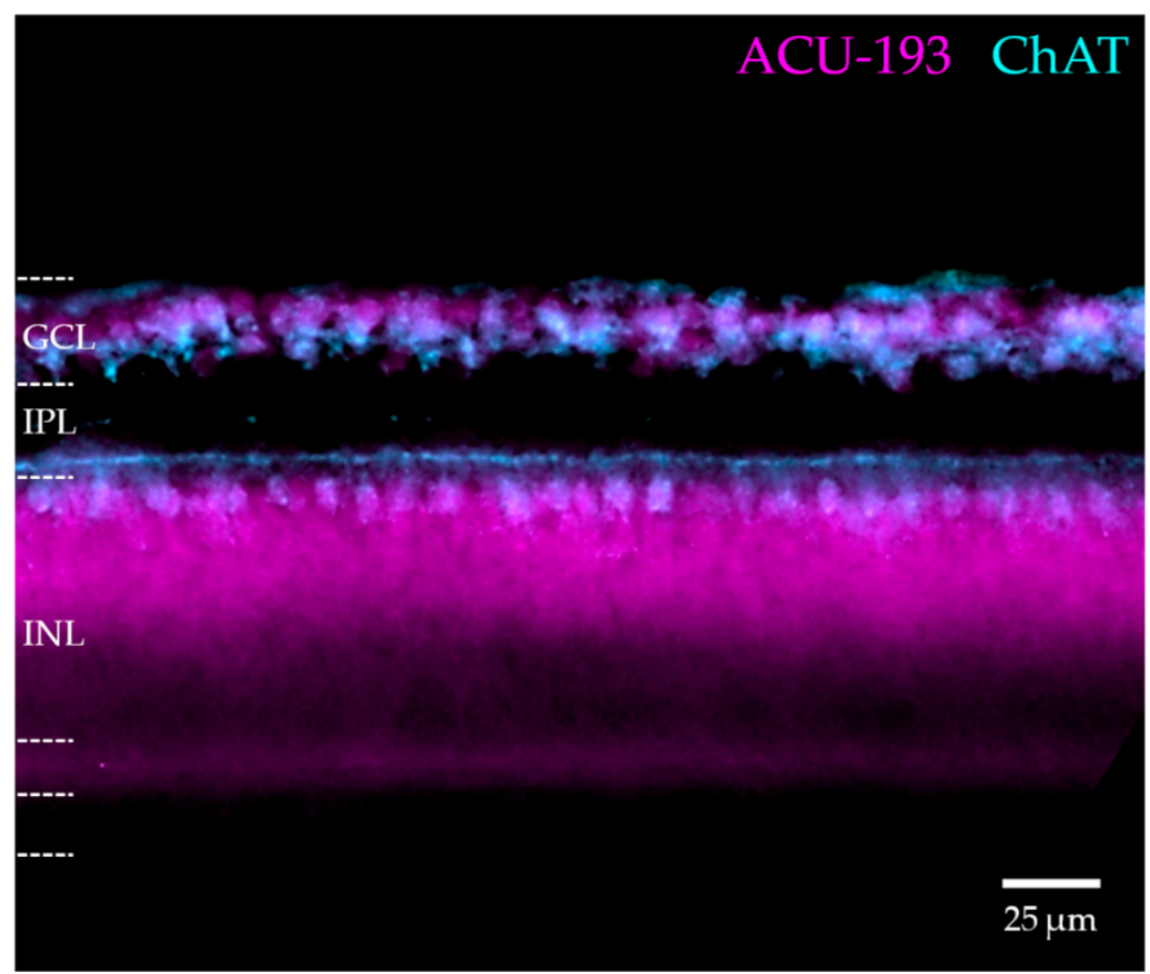

Figure 6. Embryonic cholinergic amacrine cells manifest ACU193-targeted A $\beta$ Os. Retinas from embryonic day E14 were double labelled for A 3 Os using ACU193 (magenta) and for ChAT using an antibody that was a gift from Dr. Miles Epstein (cyan). (Magenta) A $\beta O$ immunoreactivity is prominent in the GCL and inner INL. (Cyan) ChAT immunoreactivity appears in the inner INL, in processes projecting from these cells into the outer IPL, and in putative displaced amacrine cells in the ganglion cell layer. Blue/white represents areas of colocalization. Scale bar is $25 \mu \mathrm{m}$. N = 2.

\subsection{A $\mathrm{O} O$ Proteoforms Differ in Spatiotemporal Expression}

Similarities in the distribution of NU2- and ACU193-targeted A $\beta O$ s at day E14 led us to investigate their relative expression at other ages. To begin, sections from retinas of embryos at ages E8, E14, and E20 were labeled with NU2. For consistency, all images were taken from the central retina, which matures the most quickly. The results showed that the spatiotemporal expression of $\mathrm{A} \beta \mathrm{O}$ s detected by NU2 was highly regulated (Figure 7). An especially salient feature was the pronounced downregulation seen at E20. Over the full time course, the NU2 signal first appeared in the inner retina, spread outward in a cell-selective fashion, and then virtually disappeared as the retina matured. The presence of NU2-positive A $\beta O$ s in the outer retina can be seen more readily in this developmental study than in the restricted image shown in Figure 4. Control images obtained with secondary but not primary antibodies were dark for this series as well as those below. The period during which the $\mathrm{A} \beta \mathrm{O}$ s manifested most abundantly is associated with extensive morphogenic activity $[27,76]$. As shown later, the presence of $\mathrm{A} \beta \mathrm{O}$ s appears to be required for normal morphogenesis to occur.

The A $\beta$ Os detected by ACU193, unlike those detected by NU2, did not show downregulation (Figure 8). ACU193-positive cells first appeared at the inner surface of the retina, with staining at E8 in the nerve fiber layer (NFL), GCL, IPL, and inner INL. At E14, ACU193 oligomers were particularly abundant in amacrine cells. At E20, they still spanned the retina, appearing in ganglion cells (GCs), in amacrine cells (ACs), in apparent bipolar cells (BCs), in horizontal cells (HCs), and in the retina pigmented epithelium (RPE). It is notable that both ACU193 and NU2 detected A $3 \mathrm{Os}$ in E14 amacrine cells (Figures 5 and 6), but at E20 only ACU193 A $\beta$ Os were evident. The data are in harmony with the presence of at least two different proteoforms in the same E14 amacrine cells. 

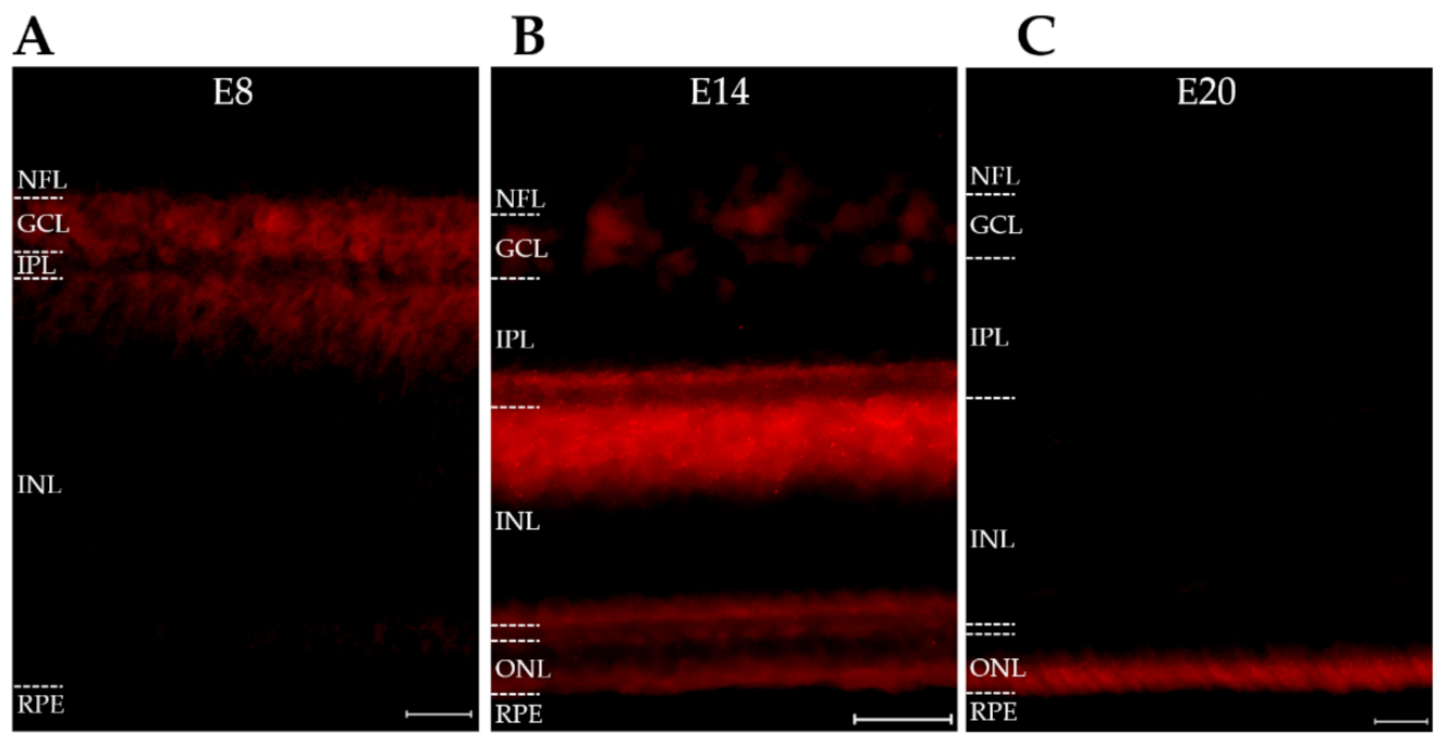

Figure 7. NU2-targeted $\mathrm{A} \beta \mathrm{O}$ proteoforms in the developing retina are transient and show complex spatiotemporal regulation. Retinas from embryonic days E8, E14, and E20 were stained for A $\beta$ Os using the selective mouse monoclonal antibody NU2 (red). (A) E8 immunoreactivity is present in the GCL, faintly in the nascent IPL, and the inner INL. (B) E14 immunoreactivity is present in the GCL but is otherwise highly localized to the interface between the IPL and INL, as well as flanking the OPL. The outer IPL shows specific sub-banding. (C) E20 immunoreactivity is largely gone, localizing only to the outer ONL. As detected by NU2, A $\beta O$ expression manifests as a wave that progresses from the inner to outer retina and then downregulates. Scale bar is $25 \mu \mathrm{m} . \mathrm{N}=2$.

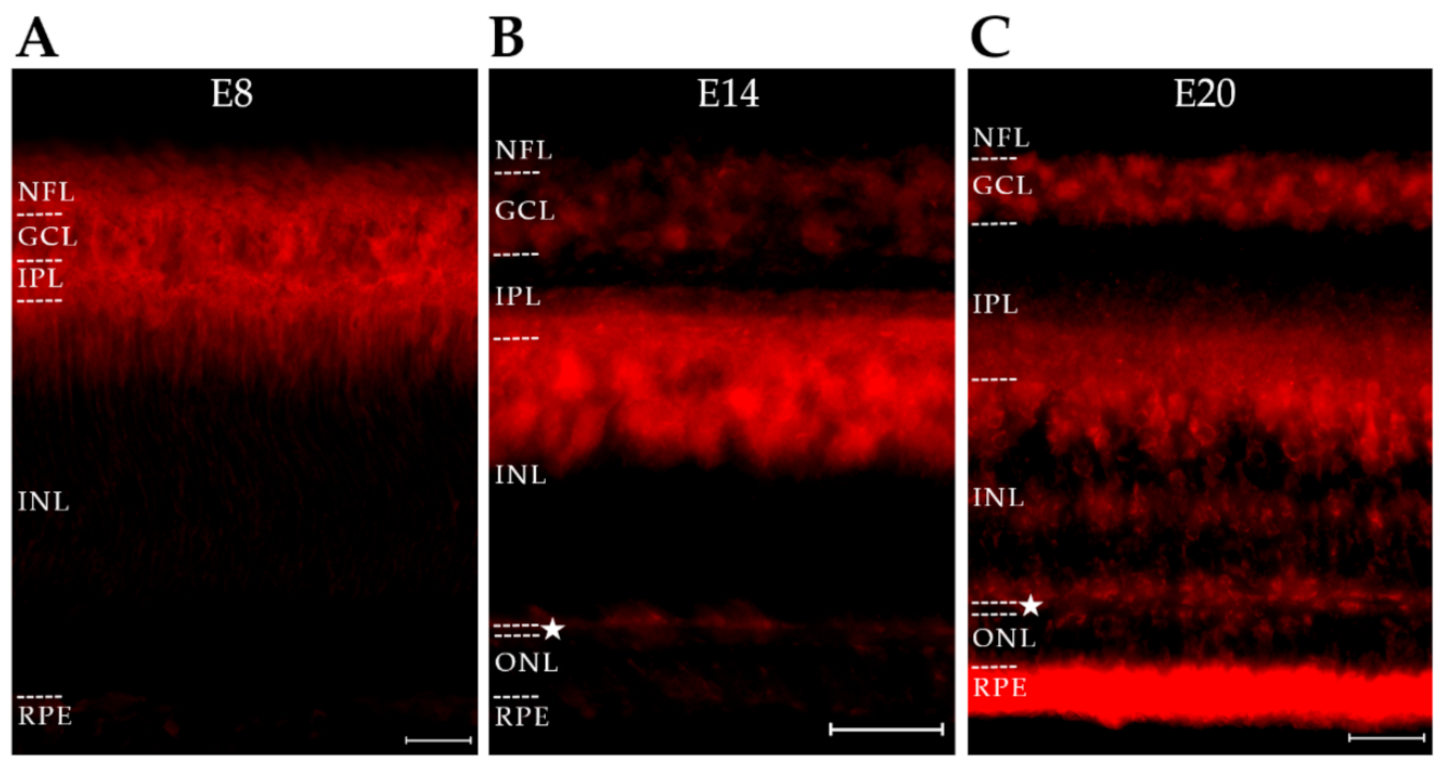

Figure 8. ACU193-targeted proteoforms develop a selective trans-retina expression that is sustained in the E20 embryo. Retinas from embryonic days E8, E14, and E20 were stained for A $\beta$ Os using ACU193 (red). (A) E8 ACU193 immunoreactivity is present in the NFL, GCL, nascent IPL, and faintly in the inner INL. (B) E14 ACU193 immunoreactivity is cell specific and faintly present in the GCL with prominent staining at interface between the IPL and INL. There is a specific sub-band in the outer IPL. (C) E20 ACU193 immunoreactivity is present through all layers of the retina, prominently in the RPE but also evident in presumptive GCs, ACs, BCs, and HCs. The outer plexiform layer (OPL) is denoted with a star. Scale bar is $25 \mu \mathrm{m} . \mathrm{N}=3$. 
The expression of NU4 oligomers was also investigated and found to be different from both ACU193 and NU2 oligomers (Figure 9). NU4 A $\beta$ Os at E8 were localized to the nascent NFL, with little presence in the GCL or other cell layers. By E14, NU4 A $\beta O$ s were evident in multiple layers across the retina but were most prominent in the GCL. In contrast, NU2 and ACU193 oligomers at this age were most prominent in the amacrine cell layer. Within the IPL, the NU4 A $\beta$ Os were evident within two sub laminae that did not align with the NU2 A $\beta O$ s in the IPL. At E20, NU4 A $\beta$ Os underwent major downregulation, similar to NU2 oligomers but unlike the ACU193 oligomers. For direct comparison, the differential patterns of expression of the three types of $\mathrm{A} \beta \mathrm{O}$ s are shown side-by-side in Figure S1.
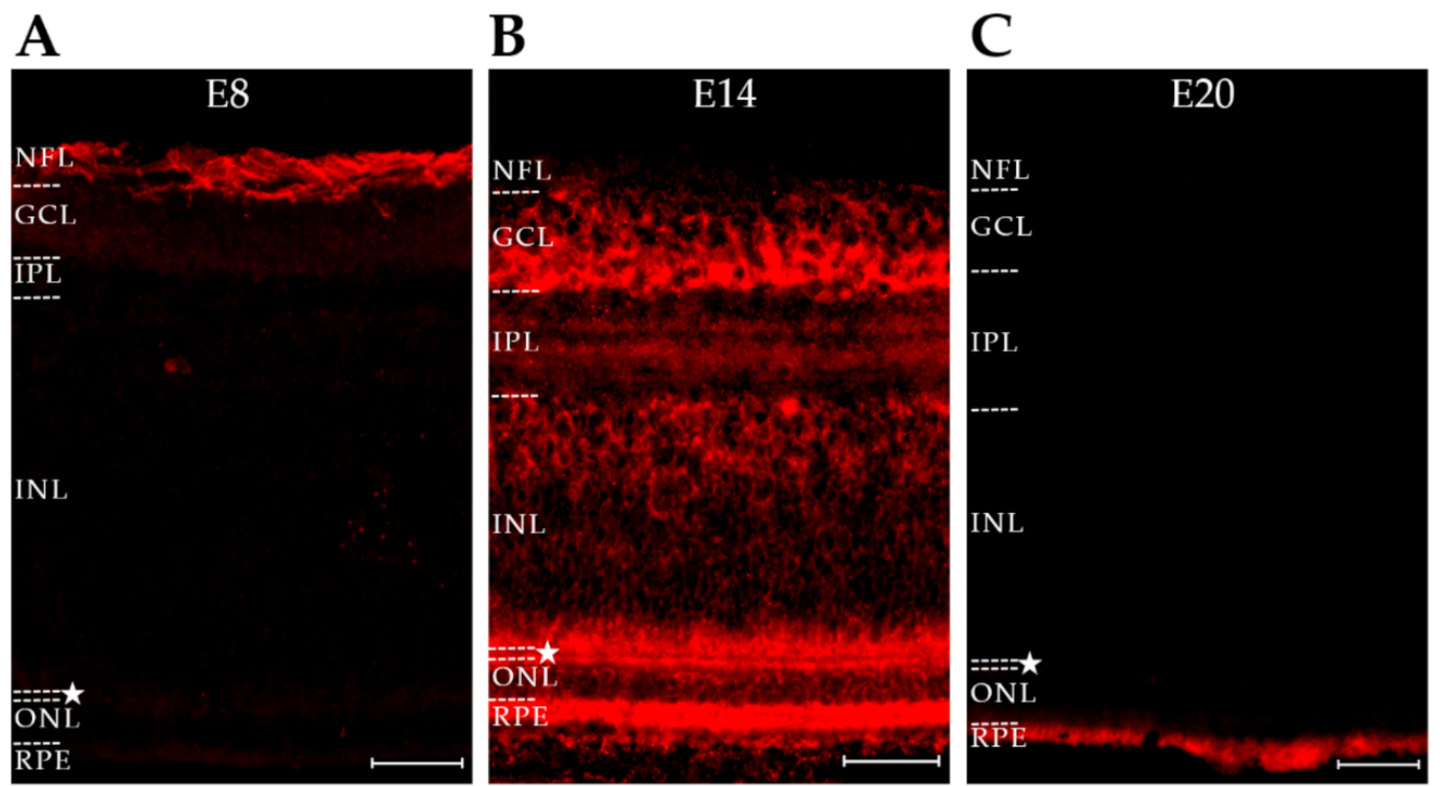

Figure 9. Transient NU4-targeted proteoforms manifest a third distinct pattern of expression. Retinas from embryonic days E8, E14, and E20 were stained for A $\beta$ Os using the selective mouse monoclonal antibody NU4 (red). (A) E8 retina A $\beta \mathrm{O}$ immunoreactivity is localized to the NFL. (B) E14 A $\beta \mathrm{O}$ immunoreactivity is spread through all retinal layers, but is most prominent in the GCL, flanking the OPL, and in the RPE; immunoreactivity also is present in two sub-bands of the IPL and the inner and middle INL. (C) E20 retina A $\beta O$ immunoreactivity is gone from most retina layers and localized to the RPE. The OPL is denoted with a star. Scale bar $=25 \mu \mathrm{m} . \mathrm{N}=4$.

The NU4 proteoform also was studied using retina cell cultures and individual cells isolated from papain-treated retinas. The cultures showed the cell-selective expression of the NU4 proteoform; the inspection of these cells showed an apparent association of A $\beta$ Os with cytoplasmic vesicles (Figure S2A). Selective expression was also evident in acutely isolated cells obtained from E14 retina treated with papain. Some neurons were double-labeled by NU4 and Brn3a, a ganglion cell marker (Figure S2B, top) and some were positive for NU4 but not Brn3a (Figure S2B, bottom). As in culture, A $\beta O$ s were evident in the neurites of isolated neurons and showed a punctate, vesicle-like distribution. The possibility that $A \beta O$ s from such vesicles might be releasable and interact with other cells is consistent with results that soluble retina extracts contained $A \beta O$ s that bound to cultured retina neurons (not shown).

The formation of $A \beta O$ s depends on $A \beta$ released by BACE, also known as beta secretase, from amyloid precursor protein (APP), both of which are known to be present in the chick retina [38,69]. BACE and APP development was tracked here using A4 and D10E5 antibodies, respectively (Figures S3 and S4). The downregulation of NU2 and NU4 oligomers cannot be explained by the simple downregulation of either APP or BACE, as both were present through E20. BACE distribution at E14 overlapped with NU2 and ACU193 oligomers in the amacrine cell region, but not with the abundant NU4 
oligomers in the GCL. BACE-1 expression at E20, however, was robust in the GCL, in harmony with the expression of ACU193 oligomers. The regulatory mechanisms of $\mathrm{A} \beta \mathrm{O}$ production and trafficking relative to APP and BACE-1 present an intriguing unknown for further investigation.

\subsection{Dependence of Retina Morphogenesis on A $\beta O$ s}

As a first step to search for the possible functions of $\mathrm{A} \beta \mathrm{O}$ s in the developing retina, we began experiments to investigate histogenesis using ex ovo embryo cultures, which have survival rates of $90 \%$ [77-82]. We found that ex ovo embryos can be virtually indistinguishable from in ovo embryos with respect to morphology and the expression of A $\beta O$ s and pTau (Figure 10). Cultured in a shell-free environment, ex ovo embryo cultures are readily accessible for manipulation via intravitreous injection.

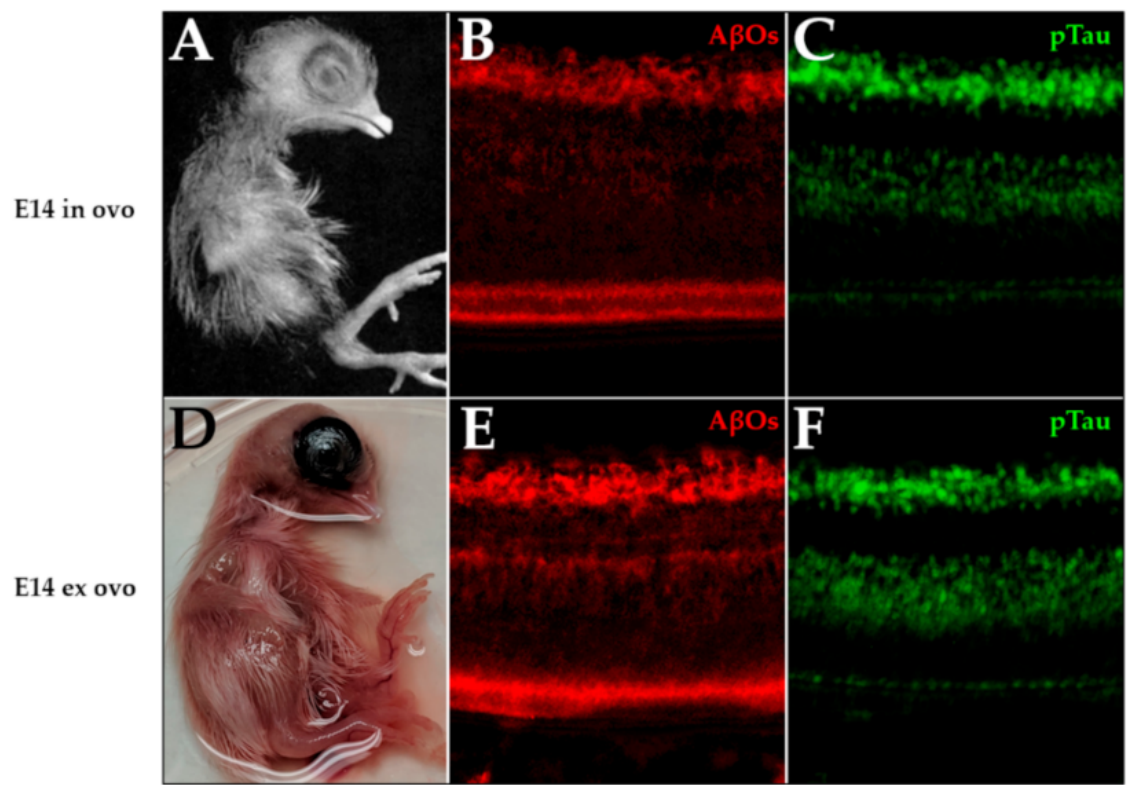

Figure 10. Cultured shell-free embryos resemble embryos maintained in ovo. Embryos were cultured shell-less, as described in the Materials and Methods section, and development was compared with embryos maintained in ovo. (A) Embryo incubated in ovo to E14 (from Hamburger Hamilton [83]), Copyright 1951 John Wiley and Sons. (D) Embryo incubated in shell-free culture to E14. (B) NU4targeted A $\beta O$ s (red) and (C) PHF-1-targeted pTau (green) in retina of E14 in ovo embryo. (E) NU4targeted A $\beta$ Os (red) and (F) PHF-1-targeted pTau (green) in retina of E14 ex ovo embryo.

We began by assessing the histogenic impact of injecting a BACE-1 inhibitor diluted in phosphate-buffered saline (PBS). A single injection was given at E9, and the retina histology was examined six days post-injection. This is a period of major retina growth and development. The injection controls comprised PBS vehicle only. In addition, as only one eye from each embryo was injected, the other eye served as a non-injected control.

The consequence of injecting BACE-1 inhibitor, but not vehicle, was retinal dysplasia. The laminar organization of the retina was disrupted by hill-like protrusions or folds that occurred predominantly along the central retina (Figure 11A). At higher magnifications, a variety of shapes were evident (Figure 11B,C; Figure 12A). Some disruption appeared as pylon-like cell assemblies projecting from the outer retina to the vitreal space, whereas others were rosette-shaped, forming separate layers. The differences in appearance may in part be explicable by the two-dimensional rather than three-dimensional projection of the tissue. Aberrant retina folds similar to those seen here have been reported for a number of pathological conditions [84-90]. No perturbations were evident in the negative controls injected with PBS vehicle or in non-injected eyes (Figure 11D,E). 


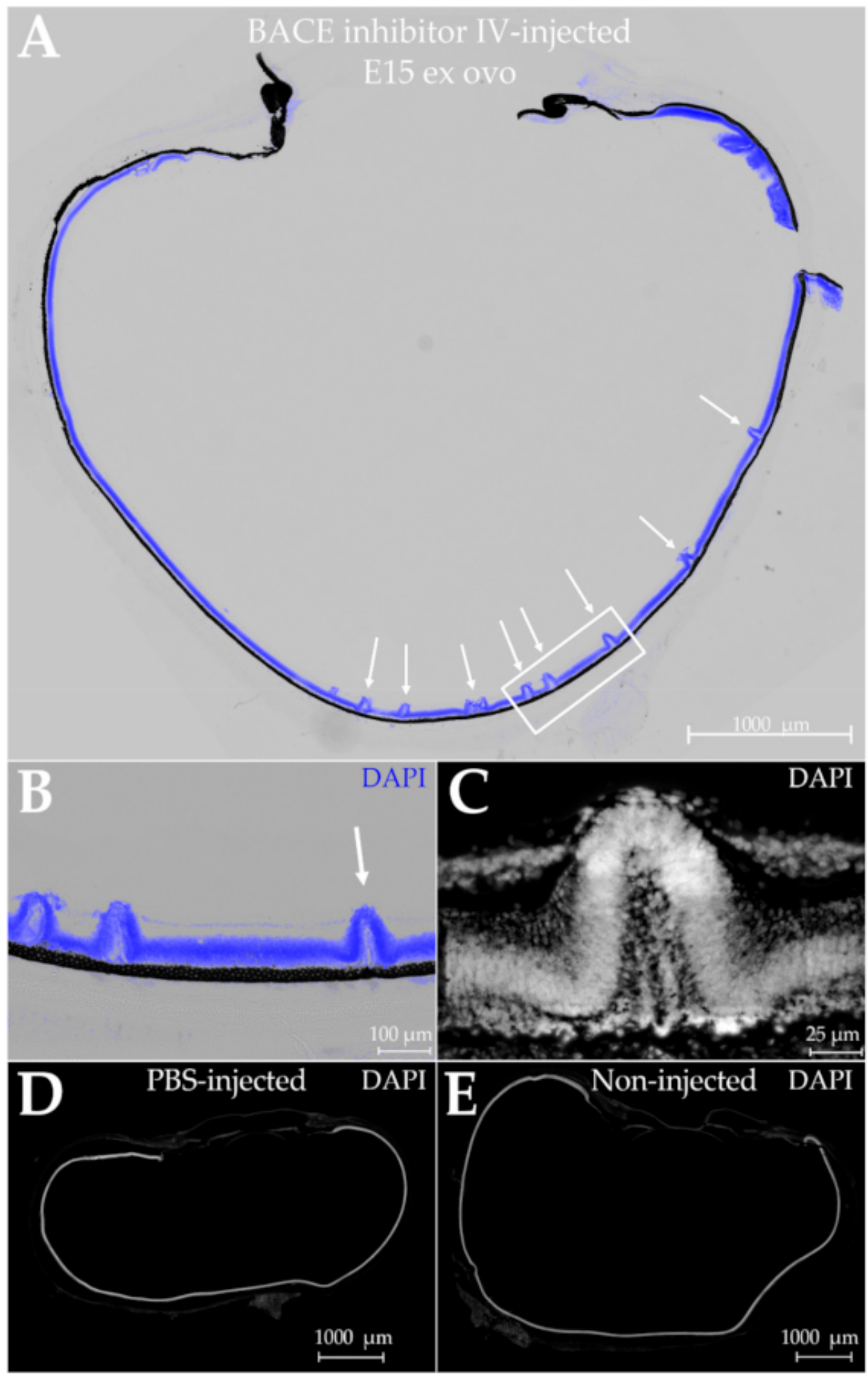

Figure 11. Intravitreal injection of shell-free embryos with a BACE-1 inhibitor induces retinal dysplasia. Ex ovo embryonic eyes were injected with $\beta$-Secretase inhibitor IV at embryonic day E9 and dissected 6 days later for inspection of retina morphology. Retinas were stained with DAPI (blue) to identify cell nuclei. (A) Laminar disruptions are present at semi-regular intervals. Scale bar is $1000 \mu \mathrm{m}$ (B) Magnified view of selected region (area enclosed in box) shows disruption of all retina layers. Scale bar is $100 \mu \mathrm{m}$. (C) High magnification view of fold (arrow shown in ' $b$ ') shows rosette formed within (DAPI in grayscale). Scale bar is $25 \mu \mathrm{m}$. (D,E) No dysplasias were observed in either PBS-injected eyes (D) or the non-injected control eyes from each embryo culture (E). Scale bars are $1000 \mu \mathrm{m} . \mathrm{N}=2$ for each condition. 

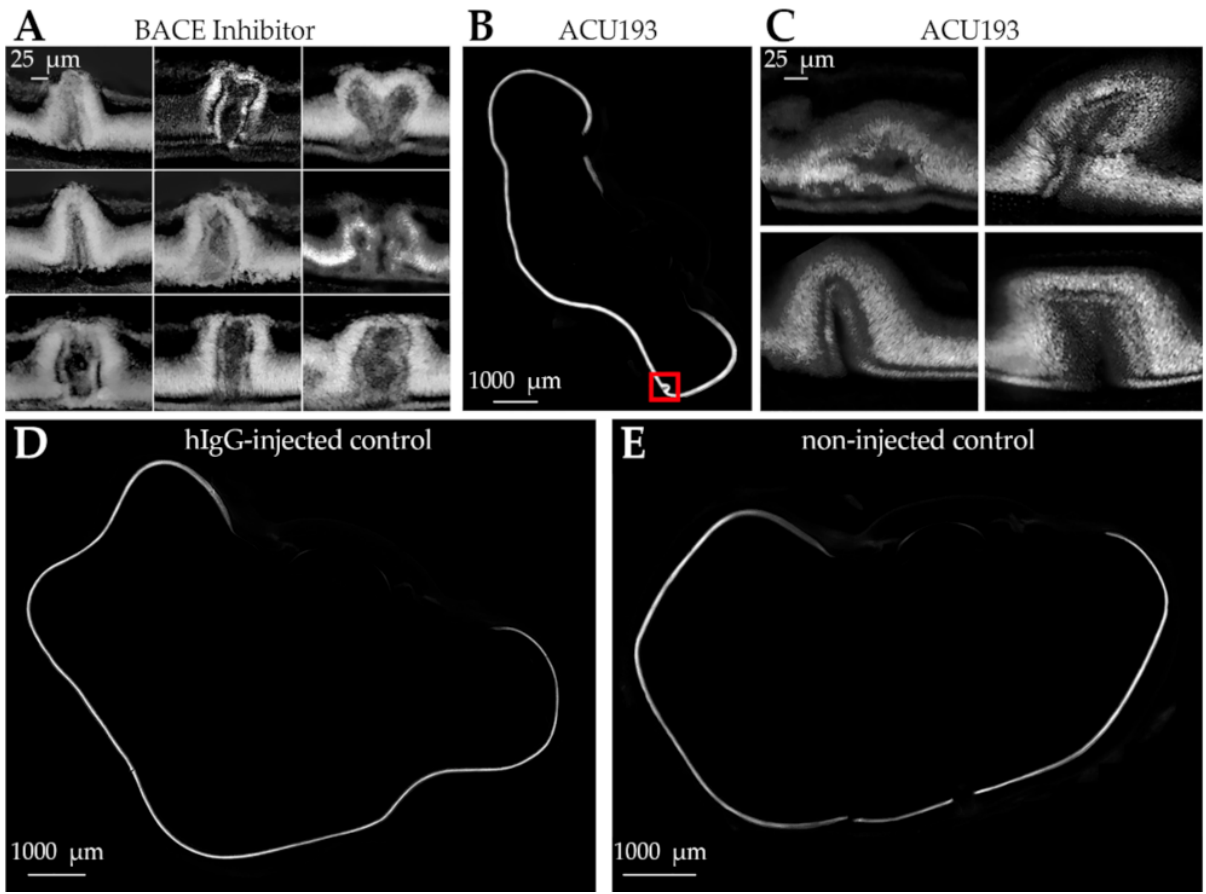

Figure 12. Laminar disruption by injected ACU193 as well as BACE inhibitor indicates a role for embryonic A $\beta O$ s in retina histogenesis. (A) Further examples of dysplasia from ex ovo embryos injected with $\beta$-Secretase inhibitor (from embryos shown in Figure 11). Retinas were stained with DAPI (grayscale) to identify cell nuclei. Laminar disruptions of various appearance extend across all retinal layers. Scale bar is $25 \mu \mathrm{m}$. (B,C) Ex ovo embryo eyes were injected with ACU193 at embryonic day 9 and processed for imaging with DAPI at day 11. Dysplasia was evident in the peripheral retina and showed folds similar to those found after BACE inhibitor injections. The red box in (B) identifies one such dysplasia. Scale bar in (B) is $1000 \mu \mathrm{m}$. Scale bar in (C) is $25 \mu \mathrm{m}$. (D,E) No disruption was observed in either control eyes injected with non-specific human IgG (D) or non-injected eyes (E). Scale bars are $1000 \mu \mathrm{m} . \mathrm{N}=2$ for each condition.

Because inhibiting BACE-1 may influence factors other than A $\beta$ Os [91], we also tested the effect of injecting the A $\beta O$-selective monoclonal antibody ACU193 (Figure 12B,C). The consequences were indistinguishable from those seen after the injection of BACE-1 inhibitor. The injections in these experiments were carried out with 9-day-old ex ovo embryos and sampling for histology was performed at 11 days. For the controls, we included eyes injected with non-specific human IgG and non-injected eyes (Figure 12D,E). As with the PBS-injected eyes, these controls showed no effect. Additionally, there was no effect of ACU193 when it was injected into developmentally stunted embryos, which had been held at $4{ }^{\circ} \mathrm{C}$ for $24 \mathrm{~h}$ after being placed in culture. Overall, all eight control injections showed no development of laminar disruptions (controls: four PBS-injected; two human IgG-injected; two ACU193-injected developmentally stunted embryos), while all four experimental treatment injections induced dysplasia (two BACE-1 inhibitor-injected; two ACU193-injected). Laminar disruptions caused by antibodies as well as BACE-1 inhibitor are consistent with the hypothesis that $\mathrm{A} \beta \mathrm{O}$ s play an essential role in the histogenic development of retinal layers.

\section{Discussion}

\subsection{AßOs, Neurotoxins Linked to AD, May Be Essential for Neurodevelopment}

Amyloid beta oligomers (A $\beta \mathrm{Os})$ are regarded as neurotoxins linked to the onset of Alzheimer's disease (AD) in the aging nervous system [14,20,22], but new findings described here show that $\mathrm{A} \beta \mathrm{O}$ s also are briefly expressed by the immature nervous system and play an essential role in neurodevelopment. Distinct $\mathrm{A} \beta \mathrm{O}$ proteoforms, identified 
by three $\mathrm{A} \beta \mathrm{O}$-selective antibodies, were found in the embryonic retina, where their expression showed a striking pattern of spatiotemporal regulation. The identification of $\mathrm{A} \beta \mathrm{Os}$ was confirmed by multiple analyses, including mass spectrometry. AD-related proteoforms of pTau, which are known to be upregulated by $\mathrm{A} \beta \mathrm{O}$ in cell and animal $\mathrm{AD}$ models $[29,41,73]$, showed analogous patterns of expression. Treatments to lower $\mathrm{A} \beta \mathrm{O}$ levels caused retinal dysplasia, a disruption of the stratified distribution of retina neurons and synapses. These results identify $\mathrm{A} \beta \mathrm{O}$ s as a novel, highly regulated factor that participate in retina morphogenesis.

It is clear that monomeric $\mathrm{A} \beta$ has a physiological role [92]; however, the current results describe a second circumstance wherein functional $\mathrm{A} \beta \mathrm{O}$ s occur in a healthy rather than degenerating CNS. The first documentation of this was during an innate immune response in which $A \beta O$ s functioned as part of the anti-viral system of the brain, investigated with respect to HSV infection [23]. Here, rather than responding to external cues, the expression of $\mathrm{A} \beta \mathrm{Os}$ was physiological, responsive to programs linked to neural development. These two circumstances, wherein the presence of $A \beta O$ s is functional rather than pathological, would help rationalize why an $A \beta$ sequence that generates oligomers toxic to mature neurons has been preserved in evolution.

The current findings were obtained using the retinas of embryonic chicks, which generate monomeric $A \beta 42$ comprising the same amino acid sequence as human $A \beta 42[38,69]$. This sequence readily oligomerizes in vitro, even at low concentrations $[5,20]$. The same self-associating sequence occurs in a number of species, but not in rodents [93], which is why the use of rodents as AD models has depended on the expression of human transgenes [7]. The chick retina is well suited for studies of neural development [51,76], and other species with human-sequence $\mathrm{A} \beta 42$ would be predicted to express transient $\mathrm{A} \beta \mathrm{Os}$ that function similarly in neural circuit formation.

\subsection{Multiple Methods Substantiated the Presence of $A \beta O$ s and Revealed Distinct A $\beta O$ Proteoforms}

Chick retina $\mathrm{A} \beta \mathrm{O}$ s were identified by antibodies previously developed to investigate synthetic $\mathrm{A} \beta \mathrm{O}$ s and brain $\mathrm{A} \beta \mathrm{Os}$ found in transgenic animal $\mathrm{AD}$ models and human samples [72,94]. Besides being detected in situ by immunofluorescence microscopy, retina $\mathrm{A} \beta \mathrm{Os}$ in the extracts were characterized by mass spectrometry and Western blots. Mass spectrometry established that putative $A \beta O$ s were in fact assemblies of the $A \beta 42$ peptide. Western blots showed the presence of several SDS-stable $A \beta O$ proteoforms that were differentially recognized by the NU2, NU4, and ACU193 monoclonal antibodies. NU2 identified bands at $\sim 45 \mathrm{kDa}$ and $\sim 37 \mathrm{kDa}$, with the $45 \mathrm{kDa}$ band being the most prominent. ACU193 identified a pair of bands at $\sim 100 \mathrm{kDa}$ and a single band at $\sim 75 \mathrm{kDa}$, with the top $\sim 100 \mathrm{kDa}$ and $-75 \mathrm{kDa}$ bands being the most prominent. NU4 identified prominent bands at $100 \mathrm{kDa}$ and just above $37 \mathrm{kDa}$. A $\beta \mathrm{O}$ proteoforms of $\sim 54 \mathrm{kDa}$ were previously found in human $\mathrm{AD}$ [2] and mouse model AD brain samples [6], while $\sim 45 \mathrm{kDa}$ proteoforms in the human AD brain were found to correlate with cholinergic pathology [95]. A possible modular relationship between the SDS-stable proteoforms in the embryonic retina and the structures found in detergent-free retina extracts is under investigation, as is their relationship to $\mathrm{AD}$ brain-derived $\mathrm{A} \beta \mathrm{Os}$.

\subsection{The A $\beta O$ Proteoforms Targeted by the Three Antibodies Show Striking Spatiotemporal Regulation, with Patterns That Were Clearly Different from Each Other}

Proteoforms detected by all three antibodies appeared by the end of the first week of development, but notable differences emerged over the next two weeks. The pattern of expression detected by NU2 and NU4 was comparable to a molecular wave that began in the inner retina, spread outward in a cell-selective manner, and then dissipated. At the time of greatest expression, roughly E12-16, A $\beta$ Os detected by NU2 and NU4 were prominent in neurons that were aligned on either side of the inner plexiform layer. The NU2 signal was prominent in the soma of amacrine cells, while the NU4 signal was prominent in the soma of ganglion cells. Within the synaptic layers that make up the IPL, NU2 showed one band 
with prominent $\mathrm{A} \beta \mathrm{O}$ labeling, while NU4 showed two bands; the three synaptic bands were not aligned. Several days later, when the retina was nearly mature, the proteoforms recognized by NU2 and NU4 were virtually gone.

The development of ACU193 proteoforms was markedly different. Most notably, when the others had largely disappeared, the proteoforms detected by ACU193 were still present. Interestingly, both ACU193-targeted and NU2-targeted proteoforms were common to virtually all cholinergic amacrine cells. This is intriguing given that NU2 proteoforms in amacrine cells were downregulated, but ACU193 proteoforms were not. Further investigations to correlate $\mathrm{A} \beta \mathrm{O}$ proteoforms with the development of particular retina circuits are just beginning. Given the distinct patterns of spatiotemporal expression, particularly the remarkable disappearance of some proteoforms late in development, the elucidation of the underlying regulatory mechanisms will be of considerable interest.

Whether the formation of $\mathrm{A} \beta \mathrm{O}$ s occurred where they were detected is not known. In acutely isolated neurons from papain-treated retinas, the $A \beta O$ s appeared to occur in cytoplasmic vesicles, in both neurites and soma, and the same was seen in cultured retina neurons. The possibility that $\mathrm{A} \beta \mathrm{O}$ s might be secreted from their sites of assembly and diffuse to distal sites is consistent with our findings that $\mathrm{A} \beta \mathrm{O}$ s in retina extracts could associate with cultured retina neurons (not shown). Current thinking favors the idea that pathological A $\beta O$ s and pTau in Alzheimer's disease are spread extracellularly by exosomes [96,97]. Retina exosomes have been isolated [98], including from embryonic avian retina [99], where they are developmentally regulated [45]. Historically, when first discovered in brain preparations, exosomes were referred to as adherons [100]. Interestingly, no amyloid plaques were observed in the immature retina. The observation that $\mathrm{A} \beta \mathrm{Os}$ and plaques are not obligately coupled was first shown in studies of the Osaka mutation, although the $A \beta$ itself comprised a modified sequence [101].

\subsection{Developing Retina and AD-Related pTau}

Besides expressing $\mathrm{A} \beta \mathrm{O}$ proteoforms, the developing retina was found to manifest an AD-related pTau proteoform recognized by the AT8 antibody, complementing earlier work [32] that identified a pTau proteoform recognized by the PHF-1 antibody. AT8 targets pSer202 in human tau, whereas PHF-1 targets a pSer396/404 epitope [73]. The spatiotemporal expression of the AT8 signal was localized to amacrine cells and disappeared by E20, a pattern notably different from the PHF-1 signal, which is prominent in ganglion cells and still robust at E20 [32]. The disparate expression of the two pTau proteoforms presumably stems from cell-specific regulatory pathways. Because A $\beta O$ s are known to upregulate pTau phosphorylated at the AT8 and PHF-1 epitopes in multiple AD models [29,31], the tau phosphorylation pathways in developing retina hypothetically could involve different $\mathrm{A} \beta \mathrm{O}$ proteoforms. In harmony with this possibility, the pTau pattern detected by AT8 was similar to that for $\mathrm{A} \beta \mathrm{O}$ s detected by NU2, whereas the prolonged presence of pTau detected by PHF-1 was similar to that of A $\beta$ Os detected by ACU193. Such modular signaling pathways would enrich the mechanisms available for the complex spatiotemporal regulation needed to establish retina circuitry.

\subsection{Investigations into Possible Functions of A Just Beginning}

As a first step, ex ovo embryo cultures were established to test if injecting agents that lower $\mathrm{A} \beta \mathrm{O}$ levels might cause readily observable anomalies in histogenesis. We found that untreated ex ovo embryos appeared normal with respect to morphology, as previously shown by others [78-82], and that their retinas showed the same stratification of $A \beta O$ s and pTau as observed in ovo. When embryos were given intravitreal injections of a $\beta$-secretase inhibitor or the A $\beta O$-selective antibody ACU193, retinal dysplasia was evident. Neurons from the outer retina did not undergo proper stratification, but instead generated aberrant folds in the tissue. The ectopic bands of cells appeared cohesive but extended all the way to the ganglion cell layer. Efforts to identify the ectopic cells and the mechanism(s) by 
which $\mathrm{A} \beta \mathrm{O}$ s influence retina histogenesis are underway. The dysplasia observed here is similar to the disruption of laminar organization reported for retinas subjected to various pathological conditions [86,88-90,102-104].

$\mathrm{A} \beta \mathrm{O}$ s in various $\mathrm{AD}$ models induce selective synapse elimination and nerve cell death $[20,105]$. These are major pathologies in AD [106-108]; however, synapse elimination and nerve cell death also are important events in neurodevelopment [109-112]. Interestingly, $\mathrm{PiRB}$, which is a membrane protein involved in developmental synapse pruning [113], has been identified as an $\mathrm{A} \beta \mathrm{O}$ receptor [114]. It thus is feasible that $\mathrm{A} \beta \mathrm{Os}$, in addition to helping establish the stratification of retina nerve cell layers, may play additional important roles during neurodevelopment, such as the pruning of excess synapses and neurons.

\subsection{Important Questions for the Future}

Because the transient expression of $A \beta O$ s during neural development is a new-found phenomenon, many questions remain to be answered, but three are particularly intriguing. First, the mechanisms that mediate the role of $\mathrm{A} \beta \mathrm{O}$ s in cell placement and lamination are unknown, but they plausibly may involve tau. Tau is a multi-functional protein known for its impact on microtubules [115]; however, it also can function in cell-cell interactions, mitosis, and migration [116]. Tau is known to mediate at least some of the toxic effects of $\mathrm{A} \beta \mathrm{Os}$ in AD models $[30,43,64]$. While current evidence is consistent with a tau-A $\beta \mathrm{O}$ mechanism in development, precedents exist for additional possibilities. A $\beta O$ s added to culture models, for example, influence cholinergic and glutamatergic signaling [117,118], and both transmitters can influence cell morphology and phenotype [119-123].

Second, it remains to be seen whether the retina of humans expresses $A \beta O$ s in various degenerative pathologies. This possibility is consistent with reports linking A $\beta$ to neurodegenerative disorders of the retina, not only AD [124] but also macular degeneration and glaucoma [124-127]. In addition, experimental type diabetes in rabbits, another species which has the human $A \beta 42$ sequence, has been shown to induce retina $A \beta O$ s [128].

Third, how the downregulation of $\mathrm{A} \beta \mathrm{Os}$ in the embryonic retina is achieved is a question germane to both neurodevelopment and neurodegeneration. The presence of $\mathrm{A} \beta \mathrm{O}$ s and AD-related pTau in the embryonic CNS adds substance to early speculations that $\mathrm{AD}$ is an aberrant recapitulation of neural development [129]. The wave of $\mathrm{A} \beta \mathrm{O}$ expression that moves in a stereotypic manner across the developing retina is not unlike the stereotypic propagation of pathology that occurs in an AD brain [130-132]. The relationship between developmentally transient $\mathrm{A} \beta \mathrm{O}$ s and pathological $\mathrm{A} \beta \mathrm{O}$ s in aging is unknown but is of considerable significance. The discovery of mechanisms that downregulate $A \beta O s$ at the end of development may provide insight into why A $\beta O$ s re-emerge in AD and potentially could provide new targets for therapeutic intervention.

\section{Materials and Methods}

\subsection{Animals}

The use of animals in these experiments was in accordance with the guidelines established by the National Institutes of Health (Guide for the Care and Use of Laboratory Animals, 8th edition. National Academies Press (nih.gov)) and Northwestern University. White leghorn chickens (Gallus gallus domesticus) were obtained from Sunnyside Hatchery (Beaver Dam, WI, USA). Eggs were incubated in a Brinsea Ova-Easy Advance incubator (Brinsea, Titusville, FL, USA) at $37.5^{\circ} \mathrm{C}$ in $60 \%$ relative humidity for between 3 and 20 days.

\subsection{Materials}

All chemicals and reagents were purchased from Sigma (Sigma-Aldrich, Milwaukee, WI, USA) unless otherwise noted below. 


\subsection{Dissection, Fixation, Sectioning, and Immunohistofluorescence}

The eyes of E8, E14, and E20 embryonic chickens were dissected and fixed in 3.7\% formaldehyde in PBS (2 eyes $/ 50 \mathrm{~mL}$ ) for $24 \mathrm{~h}$ at $4{ }^{\circ} \mathrm{C}$, followed by sequential immersion in a solution of $10 \%$ then $20 \%$ sucrose-PBS for $24 \mathrm{~h}$ each at $4{ }^{\circ} \mathrm{C}$ to ensure complete fluid exchange and to cryoprotect the tissue in preparation for frozen sectioning. The eyes were then frozen in $20 \%$ sucrose-PBS and sectioned at $45 \mu \mathrm{m}$ using a microtome (Leica SM2010R; Leica Biosystems, Buffalo Grove, IL, USA) followed by submersion in Tris-buffered saline (TBS; pH 7.6). Only sections obtained from the central transverse plane containing the lens were used for immunostaining. The sections were washed three times for 10 min each in TBS followed by permeabilization in TBS containing $0.3 \%$ Triton X-100 (TBS-Tx100) three times for 15 min each. Sections were incubated in blocking buffer (TBS-Tx100; 10\% normal goat serum (NGS; Thermo Fisher, Waltham, MA, USA)) for $1 \mathrm{~h}$ at room temperature followed by primary antibodies in fresh blocking buffer for $16 \mathrm{~h}$ at $4{ }^{\circ} \mathrm{C}$. Amyloid beta oligomers were labelled with mouse NU2 or NU4 $(3.14 \mu \mathrm{g} / \mathrm{mL})$ [62], or humanized ACU193 (1 $\mathrm{gg} / \mathrm{mL}$; gift from Acumen Pharmaceuticals, Charlottesville, VA, USA). Phosphorylated tau was labelled with mouse monoclonal antibodies, either PHF-1 (1:2000; Invitrogen, Waltham, MA, USA) or AT8 $(0.4 \mu \mathrm{g} / \mathrm{mL}$; Invitrogen, Waltham, MA, USA). Amyloid precursor protein was labelled with mouse 22C11 (2 $\mathrm{gg} / \mathrm{mL}$; EMD Millipore, Burlington, MA, USA). Beta-secretase was labelled with rabbit D10E5 (1:500; Cell Signaling Technology, Danvers, MA, USA). Cholinergic amacrine cells were labelled with goat anti-choline acetyltransferase (ChAT; 1:100; \#AB144; EMD Millipore, Burlington, MA, USA) or with rabbit polyclonal anti-ChAT serum (synthesized by Dr. Michael Mäder, University of Göttingen, Germany), a gift from Miles Epstein (University of Wisconsin, Madison WI). The sections were washed three times for $15 \mathrm{~min}$ each in TBS-Tx100 and secondary antibodies were applied for $16 \mathrm{~h}$ at $4{ }^{\circ} \mathrm{C}$ in dilute blocking buffer (1:9 blocking buffer:TBS) followed by three washes for $15 \mathrm{~min}$ each in TBS. The secondary antibodies used were Alexa Fluor goat anti-mouse, goat anti-rabbit, donkey anti-goat, or goat antihuman (1:2000; Invitrogen, Waltham, MA, USA). Double-labelling with NU4 and PHF-1 was followed this protocol with the primary antibodies applied simultaneously and then the secondary antibodies applied simultaneously. Sections were immersed in Hoechst stain in TBS (1:2000; Invitrogen, Waltham, MA, USA) for $10 \mathrm{~min}$, washed three times for 10 min each in TBS, and then mounted onto slides using ProLong with DAPI (Invitrogen, Waltham, MA, USA). The slides were imaged using a fluorescent widefield microscope (Leica DM6B Widefield Fluorescent Microscope; Leica Microsystems, Buffalo Grove, IL, USA) using $10 \times$ and $20 \times$ objectives with the appropriate fluorescent filters. The Leica SP5 II confocal microscope was also used occasionally for these studies.

The double-labelling using anti-ChAT and NU2 followed a different protocol. E14 retina sections were blocked using TBS-Tx100 containing 10\% normal donkey serum (NDS; Sigma, Milwaukee, WI, USA) rather than $10 \%$ NGS for $1 \mathrm{~h}$ at room temperature. The sections were then incubated in anti-ChAT and NU2 simultaneously for $16 \mathrm{~h}$ in fresh blocking buffer containing NDS at $4^{\circ} \mathrm{C}$ and then washed three times for $15 \mathrm{~min}$ in TBS-Tx100. The donkey anti-goat secondary antibody was applied for $16 \mathrm{~h}$ at $4{ }^{\circ} \mathrm{C}$ in dilute blocking buffer followed by three washes for $15 \mathrm{~min}$ in TBS. The sections were then incubated in the goat anti-mouse secondary antibody for $16 \mathrm{~h}$ at $4{ }^{\circ} \mathrm{C}$ in dilute blocking buffer followed by another three washes for $15 \mathrm{~min}$ in TBS. The sections then followed the rest of the above protocol using the Hoechst stain.

\subsection{Immunoblot}

Western and dot immunoblots were carried out in a fashion similar to previous studies [72]. Retinas extracted from E7, E14, and E20 embryos were homogenized in $100 \mu \mathrm{L}$ of Ham's F12 medium ((+) L-glutamine; (-) phenol; Caisson Labs, Smithfield, UT, USA) containing protease inhibitors (Pierce ${ }^{\mathrm{TM}}$ Protease Inhibitor Mini Tablets, EDTA-free; Thermo Fisher, Waltham, MA, USA). Homogenates were centrifuged for $20 \mathrm{~min}$ at 14,000 rpm at $4{ }^{\circ} \mathrm{C}$ and the supernatant was collected. The total retinal protein in the supernatant was 
calculated using Pierce $^{\mathrm{TM}}$ BCA analysis (Thermo Fisher, Waltham, MA, USA). Retinal protein within the supernatant $(20 \mathrm{ug}$ ) was run on a Novex 4-20\% Tris-glycine gel (Invitrogen, Waltham, MA, USA) for Western blot at $125 \mathrm{~V}$ for $90 \mathrm{~min}$. Gel transfer was performed at $100 \mathrm{~V}$ for $1 \mathrm{~h}$ at $4{ }^{\circ} \mathrm{C}$. The dot blots used a titration of $27 \mathrm{ug}, 13.5 \mathrm{ug}, 6.75 \mathrm{ug}$, and $3.375 \mathrm{ug}$ of retinal protein within the supernatant diluted in Ham's F12 medium. Blots were blocked with TBS containing 0.1\% Tween-20 (TBS-T; pH 7.5) and 5\% non-fat milk for $1 \mathrm{~h}$ at room temperature. Amyloid beta oligomers were labelled with either mouse NU2 $(1.5 \mu \mathrm{g} / \mathrm{mL})$, mouse NU4 $(1.5 \mu \mathrm{g} / \mathrm{mL})$, or human ACU193 $(1.5 \mu \mathrm{g} / \mathrm{mL})$ diluted in blocking buffer for $90 \mathrm{~min}$ at room temperature. The blots were then washed three times for $10 \mathrm{~min}$ each in TBS-T, followed by incubation in anti-mouse HRP $(1: 20,000)$ for NU2 or NU4, or anti-human $\operatorname{HRP}$ (1:5000) for ACU193, diluted in TBS-T containing 5\% milk for $1 \mathrm{~h}$ at room temperature. Blots were then washed three times for $10 \mathrm{~min}$ each in TBS-T and rinsed three times with $\mathrm{ddH}_{2} \mathrm{O}$ prior to imaging. SuperSignal West Femto Maximum Sensitivity Substrate (Thermo Fisher, Waltham, MA, USA) was applied to blots for $1 \mathrm{~min}$ and photographed using the Azure Sapphire ${ }^{\mathrm{TM}}$ Biomolecular Imager.

\subsection{Gel-Eluted Liquid-Fraction Entrapment Electrophoresis (GELFrEE)}

For the validation of the sample preparation methodology, $1 \mathrm{uL}$ of synthetic $\mathrm{A} \beta \mathrm{O}$ standards (76 pmol) was diluted in $30 \mu \mathrm{L}$ of $66 \%$ aqueous formic acid for the disruption of A $\beta$ oligomers into monomers. Prior to mass spectrometry, $30 \mu \mathrm{L}$ of $5 \%$ aqueous acetonitrile was added to this disrupted $\mathrm{A} \beta \mathrm{O}$ sample. For the preparation of endogenous samples, a similar protocol was followed. First, a $100 \mu \mathrm{L}$ aliquot of each GELFrEE fraction was submitted to protein extraction via methanol/chloroform/water precipitation as described by Wessel et al. [133]. The extracted protein pellet was then suspended in $30 \mu \mathrm{L}$ of $66 \%$ aqueous formic acid and, prior to mass spectrometry, diluted in another $30 \mu \mathrm{L}$ of $5 \%$ aqueous acetonitrile.

\subsection{Liquid Chromatography-Mass Spectrometry (LC-MS)}

Protein samples were subjected to reversed-phase liquid chromatography (RPLC) using an Ultimate 3000 LC system (Thermo Scientific, San Jose, CA, USA). The samples were loaded onto a trap column $(20 \mathrm{~mm}, 150 \mu \mathrm{m}$ inner diameter, i.d.) packed with PLRP-S resin (Agilent, Santa Clara, CA, USA) for an initial wash. For protein separation, another in-house packed capillary PLRP-S column (200 mm, $75 \mu \mathrm{m}$ i.d.) was used. Both columns were heated at $35^{\circ} \mathrm{C}$.

For elution gradient optimization, $1 \mu \mathrm{L}$ of disrupted synthetic $\mathrm{A} \beta \mathrm{O}$ preparation was loaded onto the RPLC setup and submitted to an acetonitrile/water gradient. The gradient consisted of a ramp of solvent B from 15 to $50 \%$ in $30 \mathrm{~min}$., with a total run time of $60 \mathrm{~min}$. including the column wash (at $95 \%$ solvent B) and re-equilibration at $95 \%$ solvent A. Solvent A consisted of $5 \%$ acetonitrile and $0.2 \%$ formic acid in water, while solvent B was composed of $5 \%$ water and $0.2 \%$ formic acid in acetonitrile. For endogenous sample analysis, either $12 \mu \mathrm{L}$ (for quantitative/wider window analysis) or $6 \mu \mathrm{L}$ (for narrow-window analysis) of each resuspended protein sample were loaded onto the RPLC setup. An A $\beta$-monomertargeted gradient was performed for all endogenous samples as follows: a ramp of solvent B from 18 to $22 \%$ for $36 \mathrm{~min}$, shortly followed by another ramp from 35 to $50 \%$ for $10 \mathrm{~min}$, for a total run time of $70 \mathrm{~min}$, including column wash and re-equilibration. The outlet of the column was on-line coupled to a nanoelectrospray ionization source, to which a $\sim 2 \mathrm{kV}$ potential was applied for ionizing proteins.

Wider-window and quantitative mass-spectrometry measurements were performed using an Orbitrap Elite Hybrid mass spectrometer (Thermo Scientific, San Jose, CA, USA). The instrument cycled between a full scan (over a 500-2000 m/z window), a SIM scan (over a 901-911 $\mathrm{m} / \mathrm{z}$ window), and an MS2 scan with same isolation window and activation by high-energy collision dissociation (HCD) at a normalized collision energy (NCE) of 25. The applied resolving power was 120,000 (at $200 \mathrm{~m} / \mathrm{z}$ ), while the automatic gain control (AGC) target was set at $1 \times 10^{6}$ for SIM and full MS. MS/MS scans were recorded at a resolving 
power of $60,000\left(\right.$ at $200 \mathrm{~m} / \mathrm{z}$ ). The AGC target for the selected precursor was $1 \times 10^{6}$. All full MS, SIM, and MS/MS scans were obtained by averaging 4 microscans.

For a targeted analysis of $\mathrm{A} \beta$ monomers, narrow-window mass-spectrometry measurements were performed using a Q Exactive HF, modified as described in Belov et al. [134] (Thermo Scientific, Bremen, Germany). The instrument cycled between a full scan (over a 500-2000 $\mathrm{m} / \mathrm{z}$ window), a selected ion monitoring (SIM) scan (over a 906.4-907.8 $\mathrm{m} / \mathrm{z}$ window, to target the $5+$ charged state of oxidized A $\beta$ monomer), and an MS2 scan with same isolation window and activation by high-energy collision dissociation (HCD) at a normalized collision energy (NCE) of 25. The applied resolving power was 120,000 (at $200 \mathrm{~m} / \mathrm{z}$ ), while the automatic gain control (AGC) target was set at $2 \times 10^{4}$ for SIM and $1 \times 10^{6}$ for full MS. MS/MS scans were recorded at a resolving power of $60,000($ at $200 \mathrm{~m} / \mathrm{z})$. The AGC target for the selected precursor was $5 \times 10^{5}$. All full MS, SIM, and MS/MS scans were obtained by averaging 4 microscans.

\subsection{Label-Free Quantitative Top-Down Analysis}

For an initial survey of $\mathrm{A} \beta$ monomer presence, merged GELFrEE samples from fractions 6-12 of all studied developmental stages were analyzed by LC-MS. To avoid sample contamination by the disrupted synthetic $\mathrm{A} \beta \mathrm{O}$ preparation, following the measurement of $\mathrm{A} \beta$ monomer retention time and prior to endogenous sample analyses, both columns were discarded and new, freshly-packed columns were set up on the LC system. Furthermore, to avoid sample-to-sample contamination, a "blank" sample, consisting of pure 33\% aqueous formic acid and 5\% acetonitrile, was run in-between each consecutive sample. For the absolute quantification of the oxidized form of the $\mathrm{A} \beta$ monomer, endogenous samples for which LC-MS analyses showed $A \beta$ monomer were re-run in random order, along with $\mathrm{A} \beta$-monomer standards of known concentrations.

\subsection{Shell-Free (Ex-Ovo) Embryo Culturing}

Embryo culturing was based on the protocols developed by Dunn [77]. Eggs were incubated for 70-74 h before culturing. Clear plastic cups (9 oz. solo cups) were filled with sterile $\mathrm{ddH}_{2} \mathrm{O}\left(180 \mathrm{~mL} ; 37^{\circ} \mathrm{C}\right)$ and covered with plastic wrap to be in contact with the water. All contents of the egg were placed onto the plastic wrap. Eggshells were crushed to a powder and sprinkled onto the albumin, CALM, and yolk. Embryos were then placed into an incubator until injection or dissection. The embryos were maintained in a Thermo Scientific Series $8000 \mathrm{DH}$ incubator (Thermo Fisher, Waltham, MA, USA) at $37.5^{\circ} \mathrm{C}$ in $80 \%$ relative humidity.

\subsection{Intravitreal Injections}

Ex-ovo embryos at E9 received a $2 \mu \mathrm{L}$ injection of either $\beta$-Secretase inhibitor IV (500 nM in PBS; EMD Millipore, Burlington, MA, USA) or ACU193 (5 $\mu \mathrm{g}$ ) into the vitreous humor of the right eye and were incubated for the number of days specified in the text before the eyes were dissected for immunohistochemistry. Control injections ( $2 \mu \mathrm{L}$ of PBS or hIgG) are described in the text.

\section{Conclusions}

Amyloid beta oligomers (A $\beta \mathrm{Os}$ ) are toxins found in the aging brain, where they are linked to AD; however, this study using embryonic chick retinas has shown $\mathrm{A} \beta \mathrm{Os}$ can be linked to neurodevelopment as well as neurodegeneration. The results show that $\mathrm{A} \beta \mathrm{Os}$ are present physiologically in the embryonic chick retina, which expresses the same $\mathrm{A} \beta$ as humans and is widely used for developmental studies. $A \beta O$ s in the developing retina manifest transiently, with the location and abundance of distinct proteoforms being highly regulated and selectively associated with the transiently expressed proteoforms of pTau. Experiments with cultured embryos show these $A \beta O$ s are essential for proper retina histogenesis. The results indicate that transiently expressed $\mathrm{A} \beta \mathrm{O}$ s might constitute a 
novel type of negative growth factor, and they are in harmony with the hypothesis that neurodegeneration in AD has its roots in neurodevelopment.

Supplementary Materials: The following supporting information can be downloaded at: https:/ /www. mdpi.com/article/10.3390/ijms23042208/s1.

Author Contributions: Conceptualization, S.C.B., F.G.D.M. and W.L.K.; formal analysis, S.C.B., M.T.P., H.X., E.H., D.S.K., M.A.B. and H.S.S.; funding acquisition, S.C.B., K.L.V., S.M.P., N.L.K. and W.L.K.; investigation, S.C.B., M.T.P., H.X., E.H., D.S.K., K.S., M.A.B. and H.S.S.; methodology, S.C.B., M.T.P., M.A.B., H.S.S., K.L.V. and W.L.K.; project administration, W.L.K.; resources, N.L.K. and W.L.K.; supervision, W.L.K.; validation, S.C.B., M.T.P., H.X., E.H., M.A.B. and H.S.S.; visualization, S.C.B., M.T.P., H.X., E.H., M.A.B., H.S.S., K.L.V. and W.L.K.; writing-original draft, S.C.B., M.A.B., H.S.S. and W.L.K.; writing-review and editing, S.C.B., M.T.P., H.X., E.H., D.S.K., M.A.B., H.S.S., K.L.V., N.L.K., F.G.D.M. and W.L.K. All authors have read and agreed to the published version of the manuscript.

Funding: This research was funded by National Institutes of Health, grant number AG060203 to W.L.K. and AG063903 to W.L.K., N.L.K. and S.M.P.

Institutional Review Board Statement: This study was conducted in accordance with the Declaration of Helsinki and approved by the Institutional Review Board of Northwestern University. The Institutional Animal Care and Use Committee (IACUC) ethical review and approval were waived for this study due to the study's exclusive use of embryonic avians. OLAW does not classify embryonic avians as "live vertebrate animals" and does not regulate such research. A "Notification of Use of Avian Embryos' form was filed with Northwestern University's IACUC and was periodically reviewed to ensure no vertebrate animals were being used in the studies and that all ethical practices for invertebrate animals were being followed.

Informed Consent Statement: Not applicable.

Data Availability Statement: Data is contained within the article and Supplementary Material. Additional details about this study are available upon request from the corresponding author.

Acknowledgments: We graciously acknowledge Acumen Pharmaceuticals for their gift of the ACU193 antibody and Miles Epstein for his gift of Michael Mäder's rabbit polyclonal anti-ChAT serum. We thank Bruce Dunne for his assistance in developing successful cultures of shell-free embryos. The Biological Imaging Facility at Northwestern University (RRID:SCR_017767), graciously supported by the Chemistry for Life Processes Institute, the NU Office for Research, and the Department of Molecular Biosciences provided all microscopy equipment used for this study.

Conflicts of Interest: W.L.K. and K.L.V. own stock in Acumen Pharmaceuticals and W.L.K. is a member of the Acumen Pharmaceutical scientific board. Acumen Pharmaceuticals did not fund the research and had no role in the design of the study; in the collection, analyses, or interpretation of data; in the writing of the manuscript, or in the decision to publish the results. Acumen Pharmaceuticals did gift the use of the ACU193 antibody. All other authors declare no conflict of interest.

\section{References}

1. Kayed, R.; Head, E.; Thompson, J.L.; McIntire, T.M.; Milton, S.C.; Cotman, C.W.; Glabe, C.G. Common structure of soluble amyloid oligomers implies common mechanism of pathogenesis. Science 2003, 300, 486-489. [CrossRef] [PubMed]

2. Gong, Y.; Chang, L.; Viola, K.L.; Lacor, P.N.; Lambert, M.P.; Finch, C.E.; Krafft, G.A.; Klein, W.L. Alzheimer's disease-affected brain: Presence of oligomeric A beta ligands (ADDLs) suggests a molecular basis for reversible memory loss. Proc. Natl. Acad. Sci. USA 2003, 100, 10417-10422. [CrossRef] [PubMed]

3. Georganopoulou, D.G.; Chang, L.; Nam, J.M.; Thaxton, C.S.; Mufson, E.J.; Klein, W.L.; Mirkin, C.A. Nanoparticle-based detection in cerebral spinal fluid of a soluble pathogenic biomarker for Alzheimer's disease. Proc. Natl. Acad. Sci. USA 2005, 102, 2273-2276. [CrossRef] [PubMed]

4. Ferreira, S.T.; Lourenco, M.V.; Oliveira, M.M.; De Felice, F.G. Soluble amyloid-beta oligomers as synaptotoxins leading to cognitive impairment in Alzheimer's disease. Front. Cell. Neurosci. 2015, 9, 191. [CrossRef] [PubMed]

5. Chang, L.; Bakhos, L.; Wang, Z.; Venton, D.L.; Klein, W.L. Femtomole immunodetection of synthetic and endogenous amyloidbeta oligomers and its application to Alzheimer's disease drug candidate screening. J. Mol. Neurosci. MN 2003, 20, 305-313. [CrossRef] 
6. Lesne, S.; Koh, M.T.; Kotilinek, L.; Kayed, R.; Glabe, C.G.; Yang, A.; Gallagher, M.; Ashe, K.H. A specific amyloid-beta protein assembly in the brain impairs memory. Nature 2006, 440, 352-357. [CrossRef]

7. Oddo, S.; Caccamo, A.; Tran, L.; Lambert, M.P.; Glabe, C.G.; Klein, W.L.; LaFerla, F.M. Temporal profile of amyloid-beta (Abeta) oligomerization in an in vivo model of Alzheimer disease. A link between Abeta and tau pathology. J. Biol. Chem. 2006, 281, 1599-1604. [CrossRef]

8. Ferretti, M.T.; Partridge, V.; Leon, W.C.; Canneva, F.; Allard, S.; Arvanitis, D.N.; Vercauteren, F.; Houle, D.; Ducatenzeiler, A.; Klein, W.L.; et al. Transgenic mice as a model of pre-clinical Alzheimer's disease. Curr. Alzheimer Res. 2011, 8, 4-23. [CrossRef]

9. Tomiyama, T.; Matsuyama, S.; Iso, H.; Umeda, T.; Takuma, H.; Ohnishi, K.; Ishibashi, K.; Teraoka, R.; Sakama, N.; Yamashita, T.; et al. A mouse model of amyloid beta oligomers: Their contribution to synaptic alteration, abnormal tau phosphorylation, glial activation, and neuronal loss in vivo. J. Neurosci. Off. J. Soc. Neurosci. 2010, 30, 4845-4856. [CrossRef]

10. Welikovitch, L.A.; Do Carmo, S.; Magloczky, Z.; Malcolm, J.C.; Loke, J.; Klein, W.L.; Freund, T.; Cuello, A.C. Early intraneuronal amyloid triggers neuron-derived inflammatory signaling in APP transgenic rats and human brain. Proc. Natl. Acad. Sci. USA 2020, 117, 6844-6854. [CrossRef]

11. Klein, W.L.; Krafft, G.A.; Finch, C.E. Targeting small Abeta oligomers: The solution to an Alzheimer's disease conundrum? Trends Neurosci. 2001, 24, 219-224. [CrossRef]

12. Walsh, D.M.; Klyubin, I.; Shankar, G.M.; Townsend, M.; Fadeeva, J.V.; Betts, V.; Podlisny, M.B.; Cleary, J.P.; Ashe, K.H.; Rowan, M.J.; et al. The role of cell-derived oligomers of Abeta in Alzheimer's disease and avenues for therapeutic intervention. Biochem. Soc. Trans. 2005, 33, 1087-1090. [CrossRef] [PubMed]

13. Ferreira, S.T.; Vieira, M.N.; De Felice, F.G. Soluble protein oligomers as emerging toxins in Alzheimer's and other amyloid diseases. IUBMB Life 2007, 59, 332-345. [CrossRef] [PubMed]

14. Mucke, L.; Selkoe, D.J. Neurotoxicity of amyloid beta-protein: Synaptic and network dysfunction. Cold Spring Harb. Perspect. Med. 2012, 2, a006338. [CrossRef] [PubMed]

15. Goure, W.F.; Krafft, G.A.; Jerecic, J.; Hefti, F. Targeting the proper amyloid-beta neuronal toxins: A path forward for Alzheimer's disease immunotherapeutics. Alzheimer's Res. Ther. 2014, 6, 42. [CrossRef]

16. Viola, K.L.; Klein, W.L. Amyloid beta oligomers in Alzheimer's disease pathogenesis, treatment, and diagnosis. Acta Neuropathol. 2015, 129, 183-206. [CrossRef]

17. Wisniewski, T.; Drummond, E. Future horizons in Alzheimer's disease research. Prog. Mol. Biol. Transl. Sci. 2019, 168, $223-241$. [CrossRef]

18. Ashe, K.H. The biogenesis and biology of amyloid beta oligomers in the brain. Alzheimer's Dement. J. Alzheimer's Assoc. 2020, 16, 1561-1567. [CrossRef]

19. Tolar, M.; Hey, J.; Power, A.; Abushakra, S. Neurotoxic Soluble Amyloid Oligomers Drive Alzheimer's Pathogenesis and Represent a Clinically Validated Target for Slowing Disease Progression. Int. J. Mol. Sci. 2021, 22, 6355. [CrossRef]

20. Lambert, M.P.; Barlow, A.K.; Chromy, B.A.; Edwards, C.; Freed, R.; Liosatos, M.; Morgan, T.E.; Rozovsky, I.; Trommer, B.; Viola, K.L.; et al. Diffusible, nonfibrillar ligands derived from Abeta1-42 are potent central nervous system neurotoxins. Proc. Natl. Acad. Sci. USA 1998, 95, 6448-6453. [CrossRef]

21. Hayden, E.Y.; Teplow, D.B. Amyloid beta-protein oligomers and Alzheimer's disease. Alzheimer's Res. Ther. 2013, 5, 60. [CrossRef]

22. Cline, E.N.; Bicca, M.A.; Viola, K.L.; Klein, W.L. The Amyloid-beta Oligomer Hypothesis: Beginning of the Third Decade. J. Alzheimer's Dis. JAD 2018, 64, S567-S610. [CrossRef] [PubMed]

23. Eimer, W.A.; Vijaya Kumar, D.K.; Navalpur Shanmugam, N.K.; Rodriguez, A.S.; Mitchell, T.; Washicosky, K.J.; Gyorgy, B.; Breakefield, X.O.; Tanzi, R.E.; Moir, R.D. Alzheimer's Disease-Associated beta-Amyloid Is Rapidly Seeded by Herpesviridae to Protect against Brain Infection. Neuron 2018, 100, 1527-1532. [CrossRef]

24. Bondareff, W.; Mountjoy, C.Q.; Roth, M. Loss of neurons of origin of the adrenergic projection to cerebral cortex (nucleus locus ceruleus) in senile dementia. Neurology 1982, 32, 164-168. [CrossRef]

25. Serrano-Pozo, A.; Frosch, M.P.; Masliah, E.; Hyman, B.T. Neuropathological alterations in Alzheimer disease. Cold Spring Harb. Perspect. Med. 2011, 1, a006189. [CrossRef]

26. Lee, H.; Brott, B.K.; Kirkby, L.A.; Adelson, J.D.; Cheng, S.; Feller, M.B.; Datwani, A.; Shatz, C.J. Synapse elimination and learning rules co-regulated by MHC class I H2-Db. Nature 2014, 509, 195-200. [CrossRef]

27. Hughes, W.F.; McLoon, S.C. Ganglion cell death during normal retinal development in the chick: Comparisons with cell death induced by early target field destruction. Exp. Neurol. 1979, 66, 587-601. [CrossRef]

28. Martin-Estebane, M.; Navascues, J.; Sierra-Martin, A.; Martin-Guerrero, S.M.; Cuadros, M.A.; Carrasco, M.C.; Marin-Teva, J.L Onset of microglial entry into developing quail retina coincides with increased expression of active caspase-3 and is mediated by extracellular ATP and UDP. PLoS ONE 2017, 12, e0182450. [CrossRef]

29. De Felice, F.G.; Wu, D.; Lambert, M.P.; Fernandez, S.J.; Velasco, P.T.; Lacor, P.N.; Bigio, E.H.; Jerecic, J.; Acton, P.J.; Shughrue, P.J.; et al. Alzheimer's disease-type neuronal tau hyperphosphorylation induced by A beta oligomers. Neurobiol. Aging 2008, 29, 1334-1347. [CrossRef] [PubMed]

30. Zempel, H.; Luedtke, J.; Kumar, Y.; Biernat, J.; Dawson, H.; Mandelkow, E.; Mandelkow, E.M. Amyloid-beta oligomers induce synaptic damage via Tau-dependent microtubule severing by TTLL6 and spastin. Embo J. 2013, 32, 2920-2937. [CrossRef] [PubMed] 
31. Forny-Germano, L.; Lyra e Silva, N.M.; Batista, A.F.; Brito-Moreira, J.; Gralle, M.; Boehnke, S.E.; Coe, B.C.; Lablans, A.; Marques, S.A.; Martinez, A.M.; et al. Alzheimer's disease-like pathology induced by amyloid-beta oligomers in nonhuman primates. J. Neurosci. Off. J. Soc. Neurosci. 2014, 34, 13629-13643. [CrossRef] [PubMed]

32. Pope, W.; Enam, S.A.; Bawa, N.; Miller, B.E.; Ghanbari, H.A.; Klein, W.L. Phosphorylated tau epitope of Alzheimer's disease is coupled to axon development in the avian central nervous system. Exp. Neurol. 1993, 120, 106-113. [CrossRef] [PubMed]

33. Rosner, H.; Rebhan, M.; Vacun, G.; Vanmechelen, E. Expression of a paired helical filament tau epitope in embryonic chicken central nervous system. Neuroreport 1994, 5, 1164-1166. [CrossRef] [PubMed]

34. Rosner, H.; Rebhan, M.; Vacun, G.; Vanmechelen, E. Developmental expression of tau proteins in the chicken and rat brain: Rapid down-regulation of a paired helical filament epitope in the rat cerebral cortex coincides with the transition from immature to adult tau isoforms. Int. J. Dev. Neurosci. 1995, 13, 607-617. [CrossRef]

35. Burack, M.A.; Halpain, S. Site-specific regulation of Alzheimer-like tau phosphorylation in living neurons. Neuroscience 1996, 72, 167-184. [CrossRef]

36. Lacor, P.N.; Buniel, M.C.; Chang, L.; Fernandez, S.J.; Gong, Y.; Viola, K.L.; Lambert, M.P.; Velasco, P.T.; Bigio, E.H.; Finch, C.E.; et al. Synaptic targeting by Alzheimer's-related amyloid beta oligomers. J. Neurosci. Off. J. Soc. Neurosci. 2004, 24, 10191-10200. [CrossRef]

37. Esselmann, H.; Maler, J.; Kunz, N.; Otto, M.; Paul, S.; Lewczuk, P.; Rüther, E.; Kornhuber, J.; Wiltfang, J. Lithium decreases secretion of $A \beta 1-42$ and C-truncated species $A \beta 1-37 / 38 / 39 / 40$ in chicken telencephalic cultures but specifically increases intracellular A $\beta 1-38$. Neurodegener. Dis. 2004, 1, 236-241. [CrossRef]

38. Mileusnic, R.; Rose, S. The chick as a model for the study of the cellular mechanisms and potential therapies for Alzheimer's disease. Int. J. Alzheimers Dis. 2010, 2010, 1-10. [CrossRef]

39. Barnes, N.Y.; Li, L.; Yoshikawa, K.; Schwartz, L.M.; Oppenheim, R.W.; Milligan, C.E. Increased production of amyloid precursor protein provides a substrate for caspase-3 in dying motoneurons. J. Neurosci. Off. J. Soc. Neurosci. 1998, 18, 5869-5880. [CrossRef]

40. Caswell, M.D.; Mok, S.S.; Henry, A.; Cappai, R.; Klug, G.; Beyreuther, K.; Masters, C.L.; Small, D.H. The amyloid beta-protein precursor of Alzheimer's disease is degraded extracellularly by a Kunitz protease inhibitor domain-sensitive trypsin-like serine protease in cultures of chick sympathetic neurons. Eur J. Biochem. 1999, 266, 509-516. [CrossRef]

41. Zempel, H.; Thies, E.; Mandelkow, E.; Mandelkow, E.M. Abeta oligomers cause localized Ca ${ }^{2+}$ elevation, missorting of endogenous Tau into dendrites, Tau phosphorylation, and destruction of microtubules and spines. J. Neurosci. Off. J. Soc. Neurosci. 2010, 30, 11938-11950. [CrossRef] [PubMed]

42. Jin, M.; Shepardson, N.; Yang, T.; Chen, G.; Walsh, D.; Selkoe, D.J. Soluble amyloid beta-protein dimers isolated from Alzheimer cortex directly induce Tau hyperphosphorylation and neuritic degeneration. Proc. Natl. Acad. Sci. USA 2011, 108, 5819-5824. [CrossRef]

43. Seward, M.E.; Swanson, E.; Norambuena, A.; Reimann, A.; Cochran, J.N.; Li, R.; Roberson, E.D.; Bloom, G.S. Amyloid-beta signals through tau to drive ectopic neuronal cell cycle re-entry in Alzheimer's disease. J. Cell Sci. 2013, 126, 1278-1286. [CrossRef] [PubMed]

44. Weysse, A.W.; Burgess, W.S. Histogenesis of the retina. Am. Nat. 1906, 40, 611-637. [CrossRef]

45. Tsui, H.C.; Pope, W.B.; Kim, C.S.; Klein, W.L. Transient expression of adheron molecules during chick retinal development. J. Neurobiol. 1992, 23, 720-738. [CrossRef]

46. Grunwald, G.B.; Fredman, P.; Magnani, J.L.; Trisler, D.; Ginsburg, V.; Nirenberg, M. Monoclonal antibody 18B8 detects gangliosides associated with neuronal differentiation and synapse formation. Proc. Natl. Acad. Sci. USA 1985, 82, 4008-4012. [CrossRef]

47. Daniloff, J.K.; Chuong, C.M.; Levi, G.; Edelman, G.M. Differential distribution of cell adhesion molecules during histogenesis of the chick nervous system. J. Neurosci. Off. J. Soc. Neurosci. 1986, 6, 739-758. [CrossRef]

48. Wong, R.O.; Yamawaki, R.M.; Shatz, C.J. Synaptic Contacts and the Transient Dendritic Spines of Developing Retinal Ganglion Cells. Eur. J. Neurosci. 1992, 4, 1387-1397. [CrossRef]

49. Harris, W.A. Cellular diversification in the vertebrate retina. Curr. Opin. Genet. Dev. 1997, 7, 651-658. [CrossRef]

50. Chow, R.L.; Lang, R.A. Early eye development in vertebrates. Annu. Rev. Cell Dev. Biol. 2001, 17, 255-296. [CrossRef]

51. Reis, R.A.; Ventura, A.L.; Kubrusly, R.C.; de Mello, M.C.; de Mello, F.G. Dopaminergic signaling in the developing retina. Brain Res. Rev. 2007, 54, 181-188. [CrossRef] [PubMed]

52. Kostadinov, D.; Sanes, J.R. Protocadherin-dependent dendritic self-avoidance regulates neural connectivity and circuit function. eLife 2015, 4, e08964. [CrossRef] [PubMed]

53. Liu, J.; Sanes, J.R. Cellular and Molecular Analysis of Dendritic Morphogenesis in a Retinal Cell Type That Senses Color Contrast and Ventral Motion. J. Neurosci. Off. J. Soc. Neurosci. 2017, 37, 12247-12262. [CrossRef] [PubMed]

54. Raeisossadati, R.; Ferrari, M.F.R.; Kihara, A.H.; AlDiri, I.; Gross, J.M. Epigenetic regulation of retinal development. Epigenetics Chromatin 2021, 14, 11. [CrossRef] [PubMed]

55. Burger, C.A.; Jiang, D.; Mackin, R.D.; Samuel, M.A. Development and maintenance of vision's first synapse. Dev. Biol 2021, 476, 218-239. [CrossRef]

56. Yamagata, M.; Yan, W.; Sanes, J.R. A cell atlas of the chick retina based on single-cell transcriptomics. eLife 2021, 10, e63907. [CrossRef]

57. Goldberg, S.; Coulombre, A.J. Topographical development of the ganglion cell fiber layer in the chick retina. A whole mount study. J. Comp. Neurol. 1972, 146, 507-517. [CrossRef] 
58. Drenhaus, U.; Morino, P.; Veh, R.W. On the development of the stratification of the inner plexiform layer in the chick retina. J. Comp. Neurol. 2003, 460,1-12. [CrossRef]

59. Thangaraj, G.; Greif, A.; Bachmann, G.; Layer, P.G. Intricate paths of cells and networks becoming "cholinergic" in the embryonic chicken retina. J. Comp. Neurol. 2012, 520, 3181-3193. [CrossRef]

60. Robles, E.; Baier, H. Assembly of synaptic laminae by axon guidance molecules. Curr. Opin. Neurobiol. 2012, 22, 799-804. [CrossRef]

61. Amini, R.; Rocha-Martins, M.; Norden, C. Neuronal Migration and Lamination in the Vertebrate Retina. Front. Neurosci. 2017, 11, 742. [CrossRef] [PubMed]

62. Wegmann, S.; Biernat, J.; Mandelkow, E. A current view on Tau protein phosphorylation in Alzheimer's disease. Curr. Opin. Neurobiol. 2021, 69, 131-138. [CrossRef] [PubMed]

63. Goedert, M.; Jakes, R.; Crowther, R.; Six, J.; Lübke, U.; Vandermeeren, M.; Cras, P.; Trojanowski, J.; Lee, V. The abnormal phosphorylation of tau protein at Ser-202 in Alzheimer disease recapitulates phosphorylation during development. Proc. Natl. Acad. Sci. USA 1993, 90, 5066-5070. [CrossRef] [PubMed]

64. Rapoport, M.; Dawson, H.N.; Binder, L.I.; Vitek, M.P.; Ferreira, A. Tau is essential to beta -amyloid-induced neurotoxicity. Proc. Natl. Acad. Sci. USA 2002, 99, 6364-6369. [CrossRef] [PubMed]

65. Shipton, O.A.; Leitz, J.R.; Dworzak, J.; Acton, C.E.; Tunbridge, E.M.; Denk, F.; Dawson, H.N.; Vitek, M.P.; Wade-Martins, R.; Paulsen, O. Tau protein is required for amyloid $\beta$-induced impairment of hippocampal long-term potentiation. J. Neurosci. 2011, 31, 1688-1692. [CrossRef] [PubMed]

66. Nussbaum, J.M.; Schilling, S.; Cynis, H.; Silva, A.; Swanson, E.; Wangsanut, T.; Tayler, K.; Wiltgen, B.; Hatami, A.; Ronicke, R.; et al. Prion-like behaviour and tau-dependent cytotoxicity of pyroglutamylated amyloid-beta. Nature 2012, 485, 651-655. [CrossRef]

67. Bloom, G.S. Amyloid-beta and tau: The trigger and bullet in Alzheimer disease pathogenesis. JAMA Neurol. 2014, 71, 505-508. [CrossRef]

68. Umeda, T.; Ono, K.; Sakai, A.; Yamashita, M.; Mizuguchi, M.; Klein, W.L.; Yamada, M.; Mori, H.; Tomiyama, T. Rifampicin is a candidate preventive medicine against amyloid-beta and tau oligomers. Brain A J. Neurol. 2016, 139, 1568-1586. [CrossRef]

69. Carrodeguas, J.A.; Rodolosse, A.; Garza, M.V.; Sanz-Clemente, A.; Perez-Pe, R.; Lacosta, A.M.; Dominguez, L.; Monleon, I.; Sanchez-Diaz, R.; Sorribas, V.; et al. The chick embryo appears as a natural model for research in beta-amyloid precursor protein processing. Neuroscience 2005, 134, 1285-1300. [CrossRef]

70. Chromy, B.A.; Nowak, R.J.; Lambert, M.P.; Viola, K.L.; Chang, L.; Velasco, P.T.; Jones, B.W.; Fernandez, S.J.; Lacor, P.N.; Horowitz, P.; et al. Self-assembly of Abeta(1-42) into globular neurotoxins. Biochemistry 2003, 42, 12749-12760. [CrossRef]

71. Walsh, D.M.; Klyubin, I.; Fadeeva, J.V.; Cullen, W.K.; Anwyl, R.; Wolfe, M.S.; Rowan, M.J.; Selkoe, D.J. Naturally secreted oligomers of amyloid beta protein potently inhibit hippocampal long-term potentiation in vivo. Nature 2002, 416, 535-539. [CrossRef] [PubMed]

72. Lambert, M.P.; Velasco, P.T.; Chang, L.; Viola, K.L.; Fernandez, S.; Lacor, P.N.; Khuon, D.; Gong, Y.; Bigio, E.H.; Shaw, P.; et al. Monoclonal antibodies that target pathological assemblies of Abeta. J. Neurochem. 2007, 100, 23-35. [CrossRef]

73. Augustinack, J.C.; Schneider, A.; Mandelkow, E.M.; Hyman, B.T. Specific tau phosphorylation sites correlate with severity of neuronal cytopathology in Alzheimer's disease. Acta Neuropathol. 2002, 103, 26-35. [CrossRef] [PubMed]

74. Knight, E.M.; Kim, S.H.; Kottwitz, J.C.; Hatami, A.; Albay, R.; Suzuki, A.; Lublin, A.; Alberini, C.M.; Klein, W.L.; Szabo, P.; et al. Effective anti-Alzheimer Abeta therapy involves depletion of specific Abeta oligomer subtypes. Neurol. Neuroimmunol. Neuroinflamm. 2016, 3, e237. [CrossRef] [PubMed]

75. Fulekar, M.H. Bioinformatics in Life and Environmental Sciences. In Bioinformatics: Applications in Life and Environmental Sciences, Fulekar, M.H., Ed.; Springer: Dordrecht, The Netherlands, 2009; pp. 1-11.

76. Mey, J.; Thanos, S. Development of the visual system of the chick: I. Cell differentiation and histogenesis. Brain Res. Rev. 2000, 32, 343-379. [CrossRef]

77. Dunn, B.E. Technique of shell-less culture of the 72-hour avian embryo. Poult. Sci. 1974, 53, 409-412. [CrossRef] [PubMed]

78. Auerbach, R.; Kubai, L.; Knighton, D.; Folkman, J. A simple procedure for the long-term cultivation of chicken embryos. Dev. Biol. 1974, 41, 391-394. [CrossRef]

79. Yalcin, H.C.; Shekhar, A.; Rane, A.A.; Butcher, J.T. An ex-ovo chicken embryo culture system suitable for imaging and microsurgery applications. JoVE (J. Vis. Exp.) 2010, 44, e2154. [CrossRef]

80. Datar, S.; Bhonde, R.R. Shell-less chick embryo culture as an alternative in vitro model to investigate glucose-induced malformations in mammalian embryos. Rev. Diabet. Stud. 2005, 2, 221. [CrossRef]

81. Dohle, D.S.; Pasa, S.D.; Gustmann, S.; Laub, M.; Wissler, J.H.; Jennissen, H.P.; Dünker, N. Chick ex ovo culture and ex ovo CAM assay: How it really works. JoVE (J. Vis. Exp.) 2009, 33, e1620.

82. Schomann, T.; Qunneis, F.; Widera, D.; Kaltschmidt, C.; Kaltschmidt, B. Improved method for ex ovo-cultivation of developing chicken embryos for human stem cell xenografts. Stem Cells Int. 2013, 2013, 1-9. [CrossRef]

83. Hamburger, V.; Hamilton, H.L. A series of normal stages in the development of the chick embryo. J. Morphol. 1951, 88, 49-92. [CrossRef] [PubMed]

84. Jesberg, D.O. Ocular malformations of the chick embryo produced by photocoagulation. Investig. Ophthalmol. 1962, 1, 348-354.

85. Manuel, M.; Pratt, T.; Liu, M.; Jeffery, G.; Price, D.J. Overexpression of Pax6 results in microphthalmia, retinal dysplasia and defective retinal ganglion cell axon guidance. BMC Dev. Biol. 2008, 8, 59. [CrossRef] 
86. Néron, B.; Marx, M.; Crisanti, P. Role of QN1 protein in cell proliferation arrest and differentiation during the neuroretina development. Mech. Dev. 2001, 102, 107-117. [CrossRef]

87. Nambu, H.; Taomoto, M.; Ogura, E.; Tsubura, A. Time-specific action of N-methyl-N-nitrosourea in the occurrence of retinal dysplasia and retinal degeneration in neonatal mice. Pathol. Int. 1998, 48, 199-205. [CrossRef]

88. Stuck, M.W.; Conley, S.M.; Naash, M.I. Defects in the outer limiting membrane are associated with rosette development in the Nrl-/- retina. PLoS ONE 2012, 7, e32484. [CrossRef]

89. Finnegan, S.; Robson, J.; Hocking, P.M.; Ali, M.; Inglehearn, C.F.; Stitt, A.; Curry, W.J. Proteomic profiling of the retinal dysplasia and degeneration chick retina. Mol. Vis. 2010, 16, 7-17.

90. Bevilaqua, M.C.; Andrade-da-Costa, B.L.; Fleming, R.L.; Dias, G.P.; da Silveirada Luz, A.C.; Nardi, A.E.; de Mello, F.G.; Gardino, P.F.; Calaza, K.C. Retinal development impairment and degenerative alterations in adult rats subjected to post-natal malnutrition. Int. J. Dev. Neurosci. 2015, 47, 172-182. [CrossRef]

91. Willem, M.; Lammich, S.; Haass, C. Function, regulation and therapeutic properties of beta-secretase (BACE1). Semin. Cell Dev. Biol. 2009, 20, 175-182. [CrossRef]

92. Giuffrida, M.L.; Caraci, F.; De Bona, P.; Pappalardo, G.; Nicoletti, F.; Rizzarelli, E.; Copani, A. The monomer state of beta-amyloid: Where the Alzheimer's disease protein meets physiology. Rev. Neurosci. 2010, 21, 83-93. [CrossRef] [PubMed]

93. Tharp, W.G.; Sarkar, I.N. Origins of amyloid-beta. BMC Genom. 2013, 14, 290. [CrossRef]

94. Lambert, M.P.; Velasco, P.T.; Viola, K.L.; Klein, W.L. Targeting generation of antibodies specific to conformational epitopes of amyloid beta-derived neurotoxins. CNS Neurol. Disord. Drug Targets 2009, 8, 65-81. [CrossRef] [PubMed]

95. Bao, F.; Wicklund, L.; Lacor, P.N.; Klein, W.L.; Nordberg, A.; Marutle, A. Different beta-amyloid oligomer assemblies in Alzheimer brains correlate with age of disease onset and impaired cholinergic activity. Neurobiol. Aging 2012, 33, 825.e1-825.e13. [CrossRef]

96. Sardar Sinha, M.; Ansell-Schultz, A.; Civitelli, L.; Hildesjo, C.; Larsson, M.; Lannfelt, L.; Ingelsson, M.; Hallbeck, M. Alzheimer's disease pathology propagation by exosomes containing toxic amyloid-beta oligomers. Acta Neuropathol. 2018, 136, 41-56. [CrossRef] [PubMed]

97. Cohn, W.; Melnik, M.; Huang, C.; Teter, B.; Chandra, S.; Zhu, C.; McIntire, L.B.; John, V.; Gylys, K.H.; Bilousova, T. Multi-Omics Analysis of Microglial Extracellular Vesicles From Human Alzheimer's Disease Brain Tissue Reveals Disease-Associated Signatures. Front. Pharmacol. 2021, 12, 766082. [CrossRef]

98. Wooff, Y.; Cioanca, A.V.; Chu-Tan, J.A.; Aggio-Bruce, R.; Schumann, U.; Natoli, R. Small-Medium Extracellular Vesicles and Their miRNA Cargo in Retinal Health and Degeneration: Mediators of Homeostasis, and Vehicles for Targeted Gene Therapy. Front. Cell. Neurosci. 2020, 14, 160. [CrossRef]

99. Schubert, D.; LaCorbiere, M.; Klier, F.G.; Birdwell, C. A role for adherons in neural retina cell adhesion. J. Cell Biol. 1983, 96, 990-998. [CrossRef]

100. Schubert, D. A Brief History of Adherons: The Discovery of Brain Exosomes. Int. J. Mol. Sci. 2020, 21, 7673. [CrossRef]

101. Tomiyama, T.; Nagata, T.; Shimada, H.; Teraoka, R.; Fukushima, A.; Kanemitsu, H.; Takuma, H.; Kuwano, R.; Imagawa, M.; Ataka, S.; et al. A new amyloid beta variant favoring oligomerization in Alzheimer's-type dementia. Ann. Neurol. 2008, 63, 377-387. [CrossRef]

102. Silverstein, A.M.; Osburn, B.I.; Prendergast, R.A. The pathogenesis of retinal dysplasia. Am. J. Ophthalmol. 1971, $72,13-21$. [CrossRef]

103. Lahav, M.; Albert, D.M.; Craft, J.L. Light and electron microscopic study of dysplastic rosette-like structures occurring in the disorganized mature retina. Albrecht Von Graefe's Arch. Clin. Exp. Ophthalmol. 1975, 195, 57-68. [CrossRef] [PubMed]

104. Gupta, R.R.; Iaboni, D.S.M.; Seamone, M.E.; Sarraf, D. Inner, outer, and full-thickness retinal folds after rhegmatogenous retinal detachment repair: A review. Surv. Ophthalmol. 2019, 64, 135-161. [CrossRef] [PubMed]

105. Batista, A.F.; Forny-Germano, L.; Clarke, J.R.; Lyra, E.S.N.M.; Brito-Moreira, J.; Boehnke, S.E.; Winterborn, A.; Coe, B.C.; Lablans, A.; Vital, J.F.; et al. The diabetes drug liraglutide reverses cognitive impairment in mice and attenuates insulin receptor and synaptic pathology in a non-human primate model of Alzheimer's disease. J. Pathol. 2018, 245, 85-100. [CrossRef]

106. Coleman, P.D.; Flood, D.G. Neuron numbers and dendritic extent in normal aging and Alzheimer's disease. Neurobiol. Aging 1987, 8, 521-545. [CrossRef]

107. Selkoe, D.J. Alzheimer's disease is a synaptic failure. Science 2002, 298, 789-791. [CrossRef]

108. Terry, R.D. Alzheimer's disease and the aging brain. J. Geriatr. Psychiatry Neurol. 2006, 19, 125-128. [CrossRef]

109. Johnson, E.M., Jr.; Deckwerth, T.L. Molecular mechanisms of developmental neuronal death. Annu. Rev. Neurosci. 1993, 16, 31-46. [CrossRef]

110. Yamaguchi, Y.; Miura, M. Programmed cell death in neurodevelopment. Dev. Cell 2015, 32, 478-490. [CrossRef]

111. Faust, T.E.; Gunner, G.; Schafer, D.P. Mechanisms governing activity-dependent synaptic pruning in the developing mammalian CNS. Nat. Rev. Neurosci. 2021, 22, 657-673. [CrossRef]

112. Limoni, G. Modelling and Refining Neuronal Circuits with Guidance Cues: Involvement of Semaphorins. Int. J. Mol. Sci. 2021, 22, 6111. [CrossRef] [PubMed]

113. Djurisic, M.; Vidal, G.S.; Mann, M.; Aharon, A.; Kim, T.; Ferrao Santos, A.; Zuo, Y.; Hubener, M.; Shatz, C.J. PirB regulates a structural substrate for cortical plasticity. Proc. Natl. Acad. Sci. USA 2013, 110, 20771-20776. [CrossRef] [PubMed] 
114. Kim, T.; Vidal, G.S.; Djurisic, M.; William, C.M.; Birnbaum, M.E.; Garcia, K.C.; Hyman, B.T.; Shatz, C.J. Human LilrB2 is a beta-amyloid receptor and its murine homolog PirB regulates synaptic plasticity in an Alzheimer's model. Science 2013, 341, 1399-1404. [CrossRef]

115. Wang, Y.; Mandelkow, E. Tau in physiology and pathology. Nat. Rev. Neurosci. 2016, 17, 5-21. [CrossRef] [PubMed]

116. Breuzard, G.; Pagano, A.; Bastonero, S.; Malesinski, S.; Parat, F.; Barbier, P.; Peyrot, V.; Kovacic, H. Tau regulates the microtubuledependent migration of glioblastoma cells via the Rho-ROCK signaling pathway. J. Cell Sci. 2019, 132, jcs.222851. [CrossRef] [PubMed]

117. Brito-Moreira, J.; Paula-Lima, A.C.; Bomfim, T.R.; Oliveira, F.B.; Sepulveda, F.J.; De Mello, F.G.; Aguayo, L.G.; Panizzutti, R.; Ferreira, S.T. Abeta oligomers induce glutamate release from hippocampal neurons. Curr. Alzheimer Res. 2011, 8, 552-562. [CrossRef]

118. Nunes-Tavares, N.; Santos, L.E.; Stutz, B.; Brito-Moreira, J.; Klein, W.L.; Ferreira, S.T.; de Mello, F.G. Inhibition of choline acetyltransferase as a mechanism for cholinergic dysfunction induced by amyloid-beta peptide oligomers. J. Biol. Chem. 2012, 287, 19377-19385. [CrossRef]

119. Mukherjee, R.S.; Hausman, R.E. Cloning of chicken choline acetyltransferase and its expression in early embryonic retina. Brain Res. Mol. Brain Res. 2004, 129, 54-66. [CrossRef]

120. Zheng, J.Q.; Felder, M.; Connor, J.A.; Poo, M.M. Turning of nerve growth cones induced by neurotransmitters. Nature 1994, 368, 140-144. [CrossRef]

121. Katz, L.C.; Shatz, C.J. Synaptic activity and the construction of cortical circuits. Science 1996, 274, 1133-1138. [CrossRef]

122. Ford, K.J.; Feller, M.B. Assembly and disassembly of a retinal cholinergic network. Vis. Neurosci. 2012, 29, 61-71. [CrossRef] [PubMed]

123. Ojeda, J.; Avila, A. Early Actions of Neurotransmitters During Cortex Development and Maturation of Reprogrammed Neurons Front. Synaptic Neurosci. 2019, 11, 33. [CrossRef] [PubMed]

124. Wang, L.; Mao, X. Role of Retinal Amyloid-beta in Neurodegenerative Diseases: Overlapping Mechanisms and Emerging Clinical Applications. Int. J. Mol. Sci. 2021, 22, 2360. [CrossRef] [PubMed]

125. Yin, H.; Chen, L.; Chen, X.; Liu, X. Soluble amyloid beta oligomers may contribute to apoptosis of retinal ganglion cells in glaucoma. Med. Hypotheses 2008, 71,77-80. [CrossRef] [PubMed]

126. Wang, M.; Su, S.; Jiang, S.; Sun, X.; Wang, J. Role of amyloid $\beta$-peptide in the pathogenesis of age-related macular degeneration. BMJ Open Ophthalmol. 2021, 6, e000774. [CrossRef]

127. Lynn, S.A.; Johnston, D.A.; Scott, J.A.; Munday, R.; Desai, R.S.; Keeling, E.; Weaterton, R.; Simpson, A.; Davis, D.; Freeman, T.; et al. Oligomeric Abeta1-42 Induces an AMD-Like Phenotype and Accumulates in Lysosomes to Impair RPE Function. Cells 2021, 10, 413. [CrossRef]

128. Bitel, C.L.; Kasinathan, C.; Kaswala, R.H.; Klein, W.L.; Frederikse, P.H. Amyloid-beta and tau pathology of Alzheimer's disease induced by diabetes in a rabbit animal model. J. Alzheimer's Dis. JAD 2012, 32, 291-305. [CrossRef]

129. Arendt, T.; Stieler, J.; Ueberham, U. Is sporadic Alzheimer's disease a developmental disorder? J. Neurochem. 2017, 143, 396-408. [CrossRef]

130. Braak, H.; Braak, E. Neuropathological stageing of Alzheimer-related changes. Acta Neuropathol. 1991, 82, 239-259. [CrossRef]

131. Khan, U.A.; Liu, L.; Provenzano, F.A.; Berman, D.E.; Profaci, C.P.; Sloan, R.; Mayeux, R.; Duff, K.E.; Small, S.A. Molecular drivers and cortical spread of lateral entorhinal cortex dysfunction in preclinical Alzheimer's disease. Nat. Neurosci. 2014, 17, 304-311. [CrossRef]

132. Trejo-Lopez, J.A.; Yachnis, A.T.; Prokop, S. Neuropathology of Alzheimer's Disease. Neurotherapeutics 2021, 1-13. [CrossRef] [PubMed]

133. Wessel, D.; Flugge, U.I. A method for the quantitative recovery of protein in dilute solution in the presence of detergents and lipids. Anal. Biochem. 1984, 138, 141-143. [CrossRef]

134. Belov, M.E.; Damoc, E.; Denisov, E.; Compton, P.D.; Horning, S.; Makarov, A.A.; Kelleher, N.L. From protein complexes to subunit backbone fragments: A multi-stage approach to native mass spectrometry. Anal. Chem. 2013, 85, 11163-11173. [CrossRef] [PubMed] 